\title{
₹USGS
}

science for a changing world

\section{Hydrogeologic Review of the Drake Cement Project, Yavapai County, Arizona}

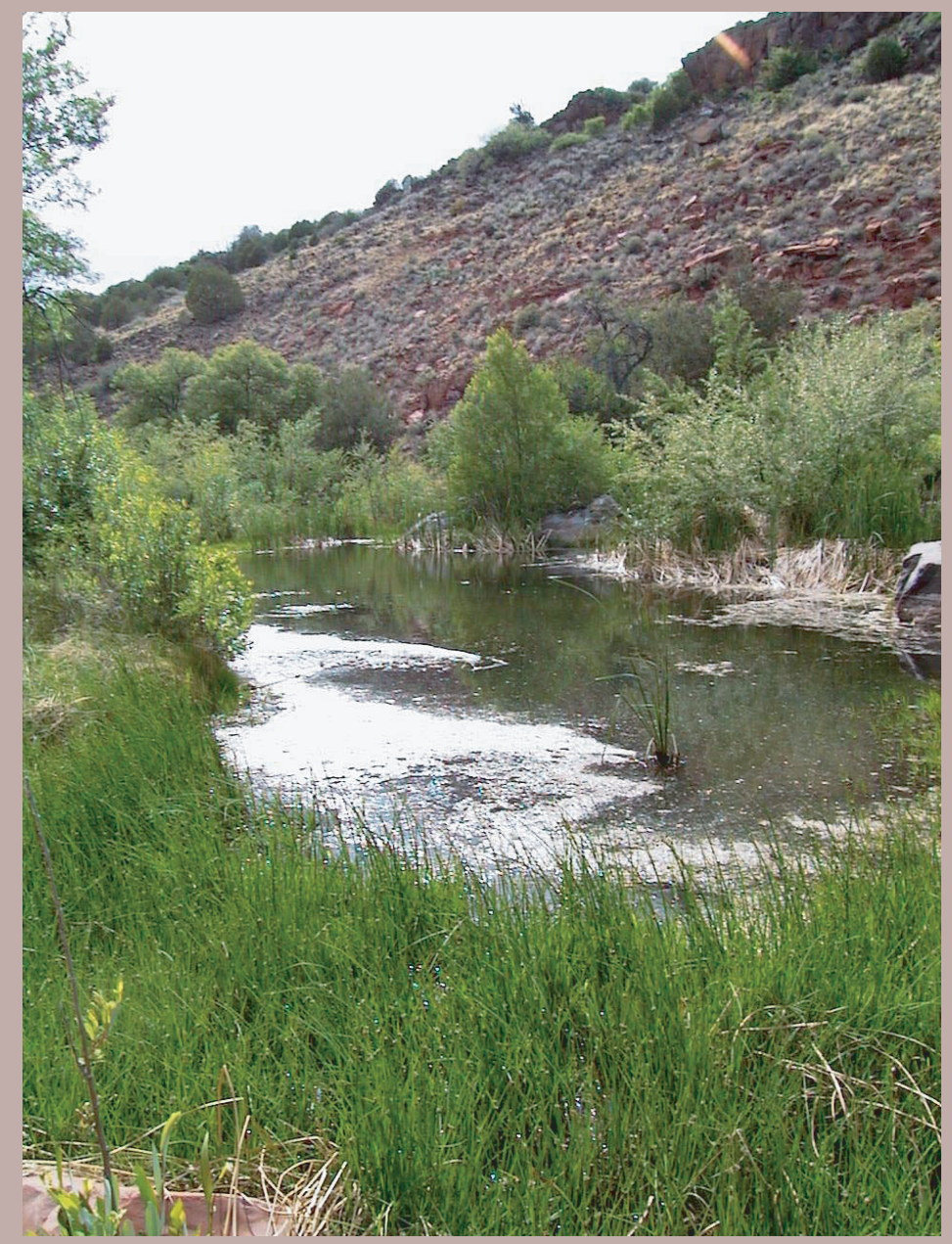

Open-File Report 2004-1439

U.S. Department of the Interior

U.S. Geological Survey 


\section{Hydrogeologic Review of the Drake Cement Project, Yavapai County, Arizona}

By Laurie Wirt

Prepared in cooperation with the Prescott National Forest

Open-File Report 2004-1439 


\section{U.S. Department of the Interior \\ Gale A. Norton, Secretary}

\section{U.S. Geological Survey \\ P. Patrick Leahy, Acting Director}

U.S. Geological Survey, Reston, Virginia: 2005

This publication is only available online at URL:

http://pubs.usgs.gov/of/2004/1439/

For information on other USGS products and ordering information: World Wide Web: http://www.usgs.gov/pubprod/

Telephone: 1-888-ASK-USGS

For more information on the USGS - the Federal source for science about the Earth, its natural and living resources, natural hazards, and the environment: World Wide Web: http://www.usgs.gov/

Telephone: 1-888-ASK-USGS

Any use of trade, product, or firm names in this publication is for descriptive purposes only and does not imply endorsement by the U.S. Government.

Although this report is in the public domain, permission must be secured from the individual copyright owners to reproduce any copyrighted materials contained within this report. 


\section{Contents}

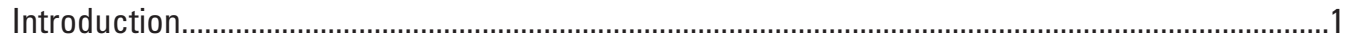

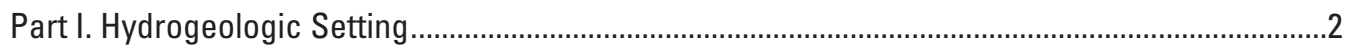

Units of the Regional Carbonate Aquifer ........................................................................................2

Water-Bearing Characteristics of the Carbonate Aquifer North of the Verde River..............10

Regional Water-Level Gradients ..........................................................................................11

Stable-Isotope Composition of Ground Water ..........................................................................15

Part II. Adequacy of Data and Soundness of Conclusions ..............................................................19

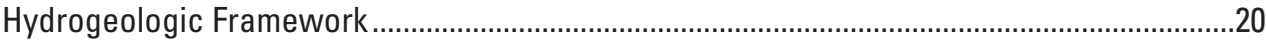

Potential Impacts to Water Resources of the Prescott National Forest

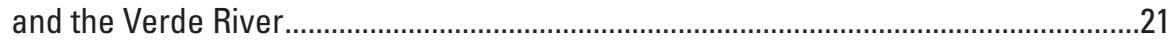

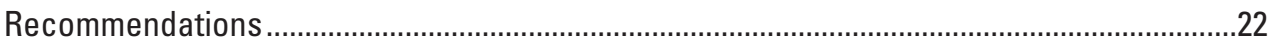

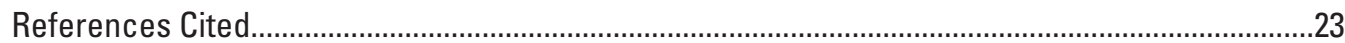

\section{Figures}

1. Shaded relief map showing upper Verde River watershed, locations of major physiographic features, and principal study area for investigations

in this report

2. Locations of known springs along the upper Verde River from Sullivan Lake to Sycamore Creek ..............................................................................................................

3. Geology map of Verde River headwaters study area ....................................................5

4. Schematic diagram of Colorado Plateau and Transition Zone geologic provinces and prominent geologic features

5. Schematic diagram of aquifer boundaries in relation to geologic provinces and prominent geologic structures.....

6. Photograph of large solution features in the Redwall Limestone in upper Verde River canyon below mouth of Government Canyon.......................................9

7. Compilation of water-level contours in the Verde River headwaters area ....................12

8. Graph showing changes in base flow with distance along the upper Verde River.......13

9. Water-level contour map of carbonate aquifer north of upper Verde River...................14

10. Photograph of King Spring in Hell Canyon. View is north. Rocks are Supai Formation capped with Tertiary basalt

11. Major water-chemistry sample groups characterized in the Verde River headwaters region.

12. Graphs showing comparison of stable-isotope data for sample groups contributing to the upper Verde River

13. Box plots of oxygen-18/oxygen-16 for sample groups contributing to the upper Verde River... 


\section{Tables}

1. Relative porosity and permeability of stratigraphic units ............................................... 8

2. Water-level measurements for wells in the carbonate aquifer north of the upper Verde River

3. Range in hydraulic conductivity of sediment and rock types found in Big and Little Chino basins

4. Statistical summary of stable-isotope sample groups by major aquifers, springs, and surrounding upland areas .

\section{Conversion Factors}

\begin{tabular}{|c|c|c|}
\hline Multiply & By & To obtain \\
\hline \multicolumn{3}{|c|}{ Length } \\
\hline inch (in.) & 2.54 & centimeter $(\mathrm{cm})$ \\
\hline inch (in.) & 25.4 & millimeter (mm) \\
\hline foot $(\mathrm{ft})$ & 0.3048 & meter $(\mathrm{m})$ \\
\hline mile (mi) & 1.609 & kilometer (km) \\
\hline \multicolumn{3}{|c|}{ Area } \\
\hline square foot $\left(\mathrm{ft}^{2}\right)$ & 0.09290 & square meter $\left(\mathrm{m}^{2}\right)$ \\
\hline square mile $\left(\mathrm{mi}^{2}\right)$ & 2.590 & square kilometer $\left(\mathrm{km}^{2}\right)$ \\
\hline \multicolumn{3}{|c|}{ Volume } \\
\hline gallon (gal) & 3.785 & liter $(\mathrm{L})$ \\
\hline gallon (gal) & 0.003785 & cubic meter $\left(\mathrm{m}^{3}\right)$ \\
\hline acre-foot (acre-ft) & 1,233 & cubic meter $\left(\mathrm{m}^{3}\right)$ \\
\hline \multicolumn{3}{|c|}{ Flow rate } \\
\hline gallon per minute (gal/min) & 0.06309 & liter per second $(\mathrm{L} / \mathrm{s})$ \\
\hline acre-foot per day (acre-ft/d) & 0.01427 & cubic meter per second $\left(\mathrm{m}^{3} / \mathrm{s}\right)$ \\
\hline acre-foot per year (acre-ft/yr) & 1,233 & cubic meter per year $\left(\mathrm{m}^{3} / \mathrm{yr}\right)$ \\
\hline cubic foot per second $\left(\mathrm{ft}^{3} / \mathrm{s}\right)$ & 0.02832 & cubic meter per second $\left(\mathrm{m}^{3} / \mathrm{s}\right)$ \\
\hline \multicolumn{3}{|c|}{ Hydraulic conductivity } \\
\hline foot per day $(\mathrm{ft} / \mathrm{d})$ & 0.3048 & meter per day $(\mathrm{m} / \mathrm{d})$ \\
\hline \multicolumn{3}{|c|}{ Hydraulic gradient } \\
\hline foot per mile (ft/mi) & 0.1894 & meter per kilometer $(\mathrm{m} / \mathrm{km})$ \\
\hline \multicolumn{3}{|c|}{ Transmissivity* } \\
\hline foot squared per day $\left(\mathrm{ft}^{2} / \mathrm{d}\right)$ & 0.09290 & meter squared per day $\left(\mathrm{m}^{2} / \mathrm{d}\right)$ \\
\hline
\end{tabular}

*Transmissivity: The standard unit for transmissivity is cubic foot per day per square foot times foot of aquifer thickness $\left[\left(\mathrm{ft}^{3} / \mathrm{d}\right) / \mathrm{ft}^{2}\right] \mathrm{ft}$. In this report, the mathematically reduced form, foot squared per day $\left(\mathrm{ft}^{2} / \mathrm{d}\right)$, converted to gallons per day per foot ( $\mathrm{gpd} / \mathrm{ft})$, is used for convenience.

Temperature in degrees Celsius $\left({ }^{\circ} \mathrm{C}\right)$ may be converted to degrees Fahrenheit $\left({ }^{\circ} \mathrm{F}\right)$ as follows:

$$
{ }^{\circ} \mathrm{F}=\left(1.8 x^{\circ} \mathrm{C}\right)+32
$$

Temperature in degrees Fahrenheit $\left({ }^{\circ} \mathrm{F}\right)$ may be converted to degrees Celsius $\left({ }^{\circ} \mathrm{C}\right)$ as follows: ${ }^{\circ} \mathrm{C}=\left({ }^{\circ} \mathrm{F}-32\right) / 1.8$ 


\section{Abbreviated Water-Quality Units}

$\delta^{18} 0$ delta notation, for the ratio of oxygen-18/oxygen-16, expressed in per mil or parts per thousand

$\delta D$ delta notation for the ratio of hydrogen-2/hydrogen-1, expressed in per mil or parts per thousand

$\%$ notation for per mil, or parts per thousand

\section{Cover Photograph}

The photograph on the cover of this report is of King Spring in Hell Canyon, Ariz. The rocks are Supai Formation capped with Tertiary basalt, and the spring discharges from the carbonate aquifer where the land surface intersects the water table. This photograph is also figure 10 of this report. 


\title{
Hydrogeologic Review of the Drake Cement Project, Yavapai County, Arizona
}

\author{
By Laurie Wirt
}

\section{Introduction}

A stated objective of the Prescott National Forest is to manage ground water for the long-term protection and enhancement of the Forest's streams, springs and seeps, and associated riparian and aquatic ecosystems (U.S. Forest Service, 2001). Ground water is an important source of water for recreation, livestock, wildlife, domestic supply, irrigation, mining, construction and other purposes within and adjacent to the Forest. The purpose of this report is to assist the Prescott National Forest in its evaluation of potential cumulative impacts relating to a proposed limestone mining project within the Prescott National Forest.

The project proponent is a company known as Drake Cement, LLC (Drake Cement). In accordance with the Prescott National Forest's scoping notice dated October 25, 2004, Drake Cement submitted a plan of operations to the Prescott National Forest in March 2004 proposing to mine limestone on unpatented claims located near Hell Canyon. Drake Cement proposes to transport limestone across Hell Canyon via a conveyor system and process the material at a privately owned cement plant that is pending construction. The processing of cement at the adjacent plant will necessitate the use of water pumped from an existing well located on the private property where the cement plant will be constructed. The anticipated water use is stated at approximately 70 acrefeet per year (62 ac-ft/yr for the plant and $8 \mathrm{ac}-\mathrm{ft} / \mathrm{yr}$ for dust suppression and mine use).

The U.S. Forest Service asked the U.S. Geological Survey to conduct a review of available data to address public concerns raised during the scoping process regarding possible impacts to the water resources of the Prescott National Forest associated with ground-water pumping. Accordingly, this report is divided into two parts.

The first part is an assessment of the geology, hydrology, and water chemistry of the regional carbonate aquifer near Drake, Arizona. Part I is largely abridged from Wirt and others (in press), and reproduces selected figures and tables from that report in their entirety. This body of work relies on numerous reports that have been generated on the geology and hydrology of the region, notably Krieger (1965);
Owen-Joyce and Bell (1983); Wallace and Laney (1976); Freethey and Anderson (1986); Ostenna and others (1993), Schwab (1995); and Knauth and Greenbie (1997). In addition, the author visited the private property where the well site is located and surrounding region, compiled publicly-available water-level measurements from the Arizona Department of Water Resources (ADWR) 55 database, and used water-quality analyses and geology maps from past and current USGS projects. The author also consulted with Mike Fayhe (USGS, Yucca Mountain project), who is experienced in interpreting aquifer tests in fractured rock and karst terrains. Lastly, the author draws on more than a decade of USGS scientific investigations in the upper Verde River watershed, including Wirt and Hjalmarson (2000), and Wirt and others (in press).

In Part II of this report, the limestone mining proposal is analyzed in the context of a prior hydrological study that was done by Southwest Groundwater Consultants (SWGC) in 2002. The SWGC report was commissioned by a prior project proponent unrelated to Drake Cement and the components of the previously proposed project differ substantially from that of the planned Drake Cement project. Notwithstanding, the SWGC report is analyzed in particular with regard to the following issues:

- Possible changes in low-flow discharge to the upper Verde River between Sullivan Lake and Perkinsville,

- Possible changes to water levels in the carbonate aquifer near Drake,

- Possible effects of sustained pumping on nearby aquifers that may be interconnected with the carbonate aquifer-specifically the Big Chino basin-fill aquifer, and

- Possible impacts to USFS wells used by grazing permit holders and to nearby perennial springs on the Prescott National Forest.

In addition, the appropriateness and adequacy of the hydrogeology information presented by SWGC (2002) is addressed; including the approach, logic, and accuracy of the arguments and conclusions. In particular, the SWGC report was examined for use of all available data, technical deficiencies, use of standard hydrologic methods, and the accuracy of 
Hydrogeologic Review of the Drake Cement Project, Yavapai County, Arizona

substantiated claims of system behavior with respect to the hydrologic resources of the Prescott National Forest. Because this consultant's report relies heavily on information presented in two earlier consultant's reports concerning the Rancho Cielo development near Paulden by Water Resource Associates (1991), and Hydrologic Consultants (1990); the technical information in these two other reports also was evaluated. This review does not evaluate other types of potential impacts to humans or wildlife such as air quality or noise.

\section{Part I. Hydrogeologic Setting}

The Drake Cement well (SB-0001) is located near the Drake railroad siding on the north rim of Hell Canyon, a tributary of the upper Verde River of north-central Arizona (figs. 1 and 2). The upper Verde River watershed drains the Transition Zone geologic province along the southwestern edge of the Colorado Plateau geologic province (figs. 3-5). The Transition Zone developed in response to tectonic uplift, rifting, and extensional movements that formed the Basin and Range province during the Tertiary period. Alluvial basins in the Transition Zone such as Big and Little Chino Valleys and Verde Valley tend to be smaller and shallower than Basin and Range valleys further south and west. Their average elevation is intermediate to the plateau rim and the southern desert basins.

As evidenced by the rugged topography of canyons, cliffs, and buttes; the upper Verde River is actively draining and eroding the southern edge of the Colorado Plateau. All basins and ranges south and west of the margin of the Colorado Plateau are in Transition Zone (Pierce, 1985). The southern boundary of the Colorado Plateau west of Drake is defined by the crest of Big Black Mesa north of Big Chino Valley (figs. 3-5; Wirt and others, in press). The southern boundary of the Colorado Plateau east of Drake is defined by the erosional escarpment of the Mogollon Rim (figs. 4 and 5). The Mogollon Rim is well-defined near the Matterhorn, a prominent topographic feature northeast of Drake. The Rim is a steep escarpment east of the Matterhorn toward Sycamore Canyon and north of Verde Valley. West of the Matterhorn, the Rim extends northward toward Ash Fork, where it is partially to completely buried by Tertiary basalt flows (DeWitt and others, in press), and consequently lacking in topographic definition. The southern boundary of the Colorado Plateau north of Drake is offset between the Matterhorn and the crest of Big Black Mesa (figs. 4 and 5). Based on this hydrogeologic framework, the Drake well draws from the regional carbonate aquifer within the Transition Zone.

Paleozoic rocks in the Verde River headwaters generally dip less than 10 degrees to the north or northeast except near monoclines (Krieger, 1965). Paleozoic sedimentary rocks exposed in Hell Canyon southeast of Drake are relatively flatlying (Krieger, 1965). West of Drake, the Limestone Canyon monocline on Big Black Mesa has near vertical overturned beds (Kreiger, 1965). The monocline is parallel to and has the same northwest trend as the Big Chino Fault (figs. 3-5).
Depending on the geologic setting, faults can serve either as conduits or barriers to ground-water movement. On a regional scale, extensional northwest-trending fractures in northern Arizona tend to be open to fluid flow (Thorstenson and Beard, 1998; L.S. Beard, oral commun., 1999). Wirt and Hjalmarson (2000) have proposed that ground water at the outlet of the Big Chino basin-fill aquifer travels from northwest to southeast parallel to the trend of the Big Chino Fault north of Paulden, Arizona. In this area, fault displacement is absent or less than $400 \mathrm{ft}$, and basin-fill deposits shallowly overlie or abut carbonate rocks (indicated by dashed basin boundary north of Paulden in figs. 3-5). Fractures and karst in the regional carbonate aquifer provide a flow path between the Big Chino basin-fill aquifer and base flow in the upper Verde River.

The three major aquifers that comprise the headwaters of the Verde River (fig. 5) - the Big and Little Chino basin-fill aquifers and the adjoining carbonate aquifer-have aquifer characteristics intermediate to those of the Basin and Range and the Colorado Plateau. The Big and Little Chino basin-fill aquifers, although smaller than typical Basin and Range basinfill aquifers farther south, have considerable storage capacity and deliver steady, reliable discharge to their outlets. The basin-fill aquifers include Tertiary volcanic rocks that resulted from Basin and Range faulting and extension, as well as alluvial sediments. The carbonate aquifer in the Transition Zone north of Big Chino Valley and the upper Verde River is the broken and eroded margin of a large regional carbonate aquifer that lies more than $3,000 \mathrm{ft}$ beneath much of the southwestern Colorado Plateau. The carbonate aquifer is partly capped by Tertiary volcanic rock and sediment, and paleochannels have been deeply filled by basalt flows in some places. Karst plays an important role in ground water movement not only for the carbonate aquifer north of the upper Verde River, but presumably underneath and along the margins of the Big Chino basin-fill aquifer where it abuts carbonate rocks (as shown by dashed basin boundaries in figs. 3-5). The relative porosity and permeability of different sedimentary rock units is summarized in table 1 , and discussed next.

\section{Units of the Regional Carbonate Aquifer}

Nearly the entire region north of the Big Chino Fault and the upper Verde River (in the Transition Zone and extending beneath the Colorado Plateau) is comprised of a continuous expanse of Paleozoic sedimentary rocks that form the carbonate aquifer (fig. 5). The carbonate aquifer near Drake consists of several Paleozoic sedimentary units, ranging in age from Cambrian to Permian. The aquifer is locally overlain by thick Tertiary basalt flows, which can fill in incised paleochannels to depths extending below the water table. In some areas, the Paleozoic and Tertiary rocks are concealed by surficial alluvium; for example the large Quaternary fan extending southeast of the Limestone Canyon Monocline and State Route 89A (fig. 3). 


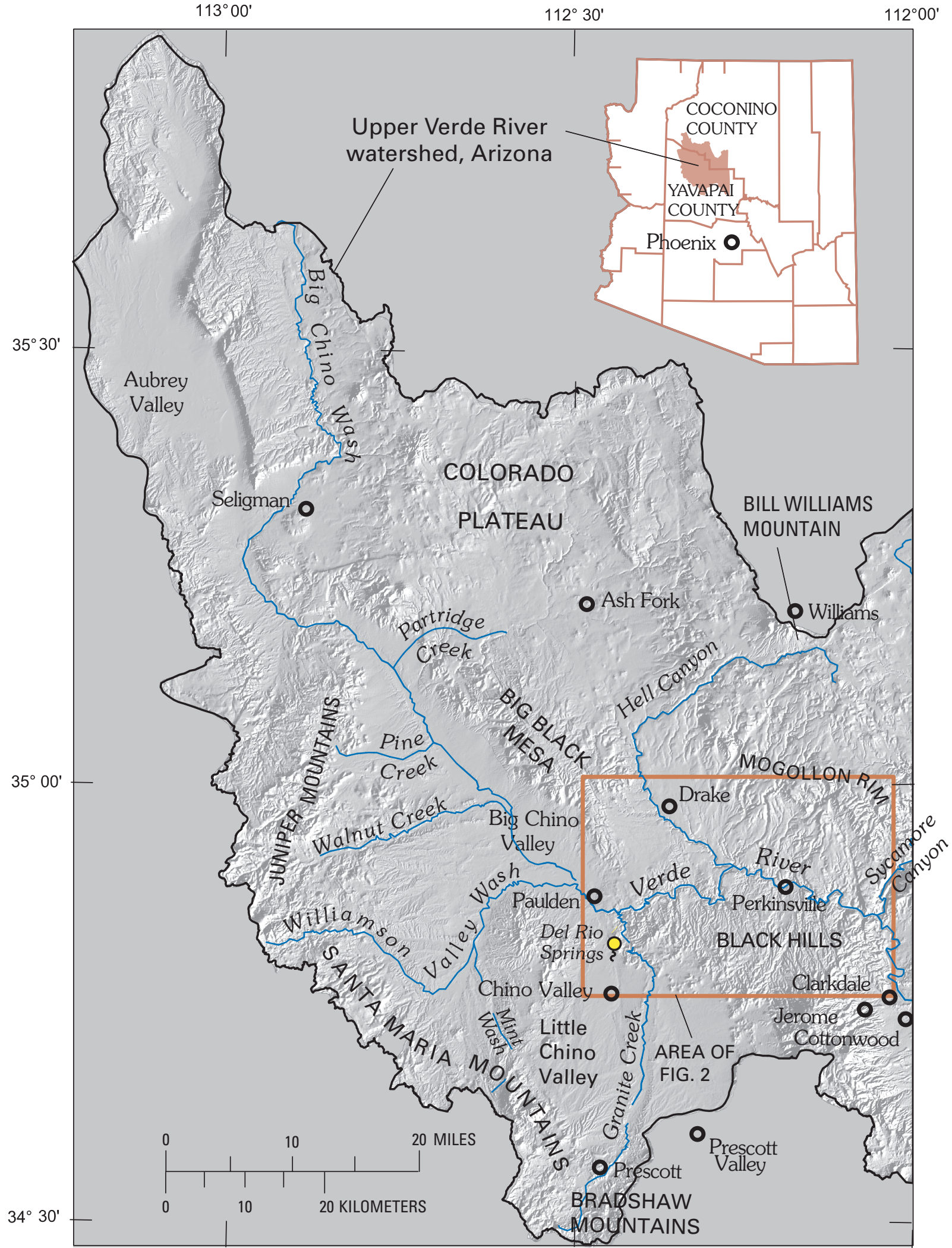

Figure 1. Shaded relief map showing upper Verde River watershed, locations of major physiographic features, and principal area for study investigations in this report. Base is from U.S. Geological Survey digital data 1:100,000; sun angle elevation is 45 degrees from southeast; azimuth is 120 degrees. 


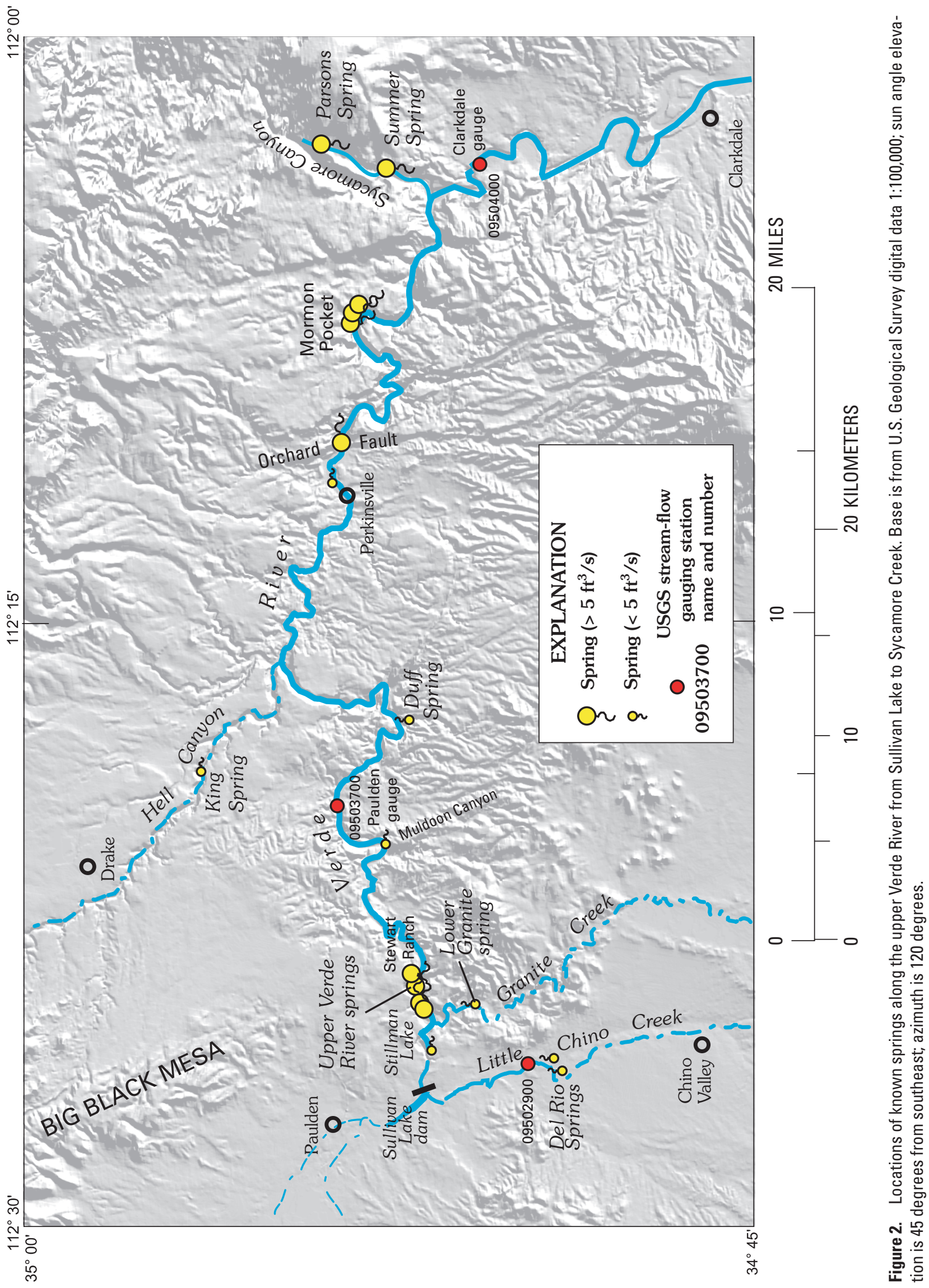




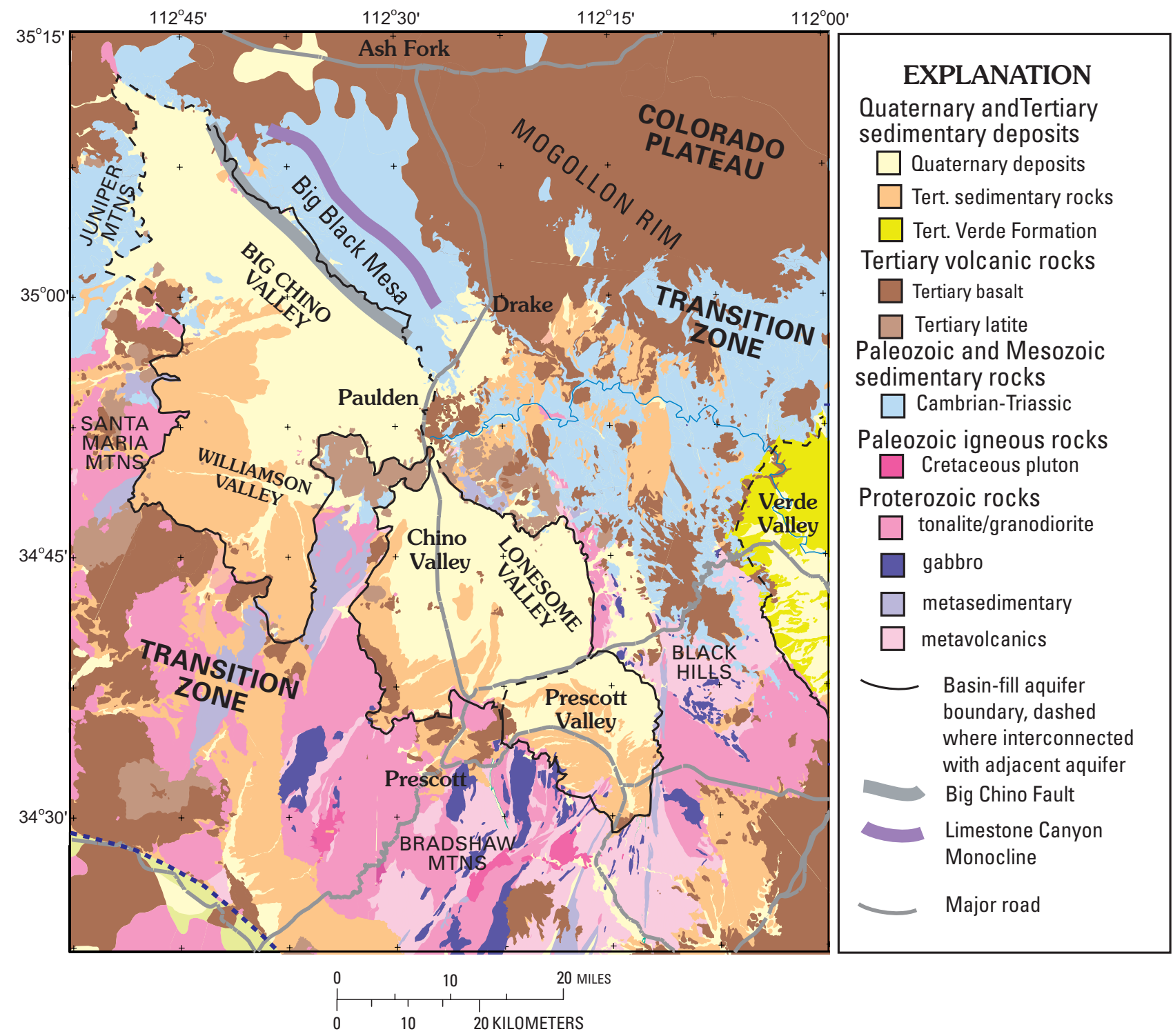

Figure 3. Geologic map of the Verde River headwaters study area (simplified from DeWitt and others, in press). Geology outside of thick dotted blue line is abridged from Reynolds (1988) and Richard and Kneale (1993). Base is from U.S. Geological Survey digital data 1: 100,000 .

The carbonate aquifer consists of several hydraulically connected limestone, dolomite, sandstone, and shale units (table 1). The units, in ascending order, include the Tapeats Sandstone and Bright Angel Shale of Cambrian age; the Martin Formation of Devonian age; the Redwall Limestone of Mississippian age; and the Supai Formation of Pennsylvanian and Permian age. The primary water-bearing unit in the Drake area is the Martin, followed to a lesser degree by the Redwall.

Owing to variations in uplift and erosion, not all Paleozoic units are preserved at all locations in the Verde River watershed. South of the upper Verde River, the Martin is usually the uppermost unit. On Big Black Mesa and north of the upper Verde River (toward Drake and east of Hell Canyon), the Redwall is the uppermost unit. Although exposed in just a few locations in Hell Canyon and along the upper Verde River canyon, the Supai is an important unit in the regional aquifer farther east in Verde Valley (Twenter and Metzger, 1963; Owen-Joyce and Bell, 1983).

The Tapeats Sandstone is the basal aquifer unit, consisting of medium-to-coarse grained feldspathic sandstone ranging in thickness from 0 to $300 \mathrm{ft}$. This formation is exposed along the base of Big Black Mesa and the Juniper Mountains, and in lower Granite Creek. In the northwestern part of Big Chino Valley, the Tapeats Sandstone is overlain by the Bright Angel Shale. In the southeastern part Big Chino Valley and near the mouth of Granite Creek, the Tapeats is overlain by a mixed carbonate and clastic unit known as the Chino Valley Formation (Hereford, 1975) of unknown age between the 

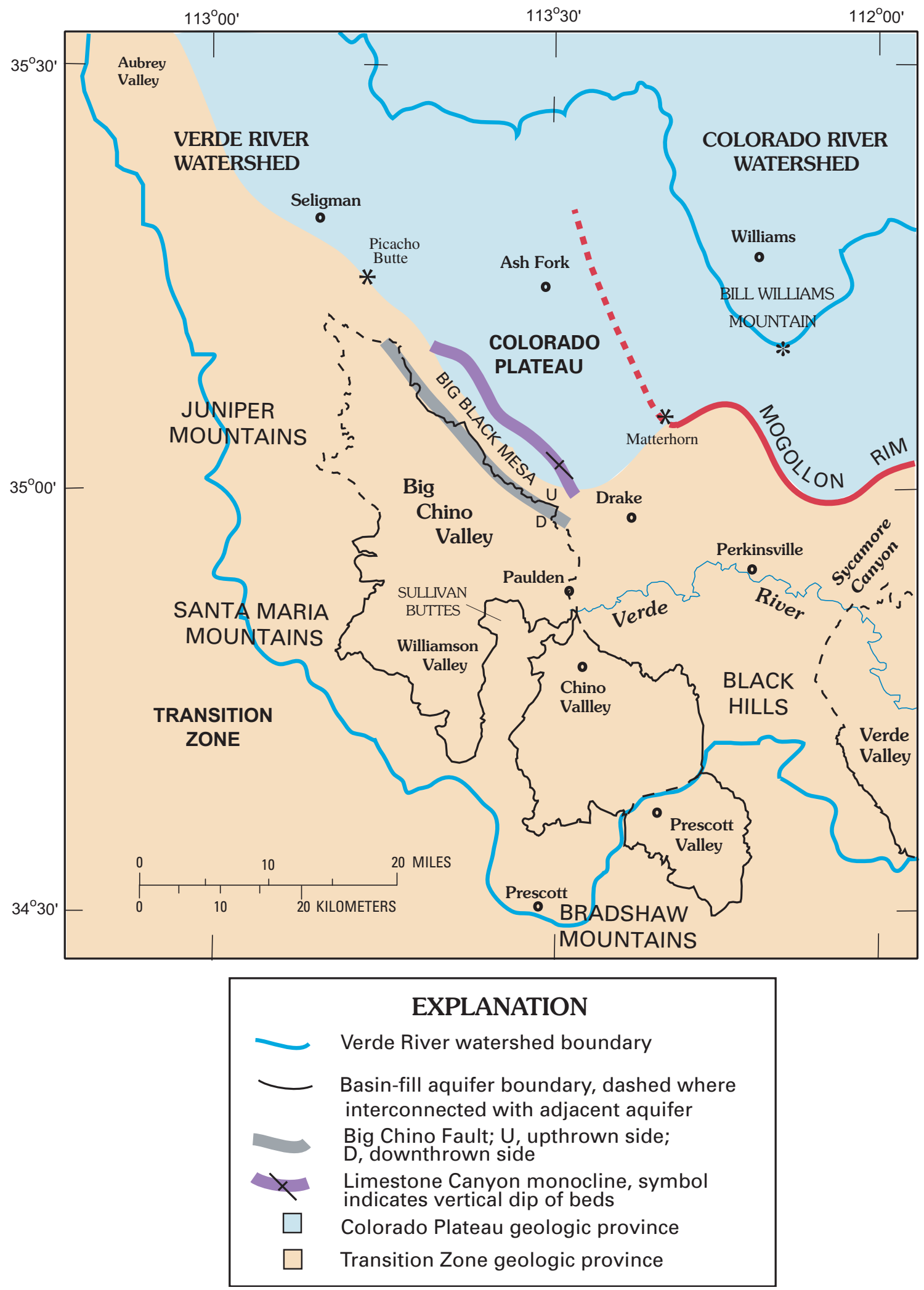

Figure 4. Schematic diagram of Colorado Plateau and Transition Zone geologic provinces and prominent geographical features, upper Verde River watershed. Base is from U.S. Geological Survey digital data 1:100,000. 


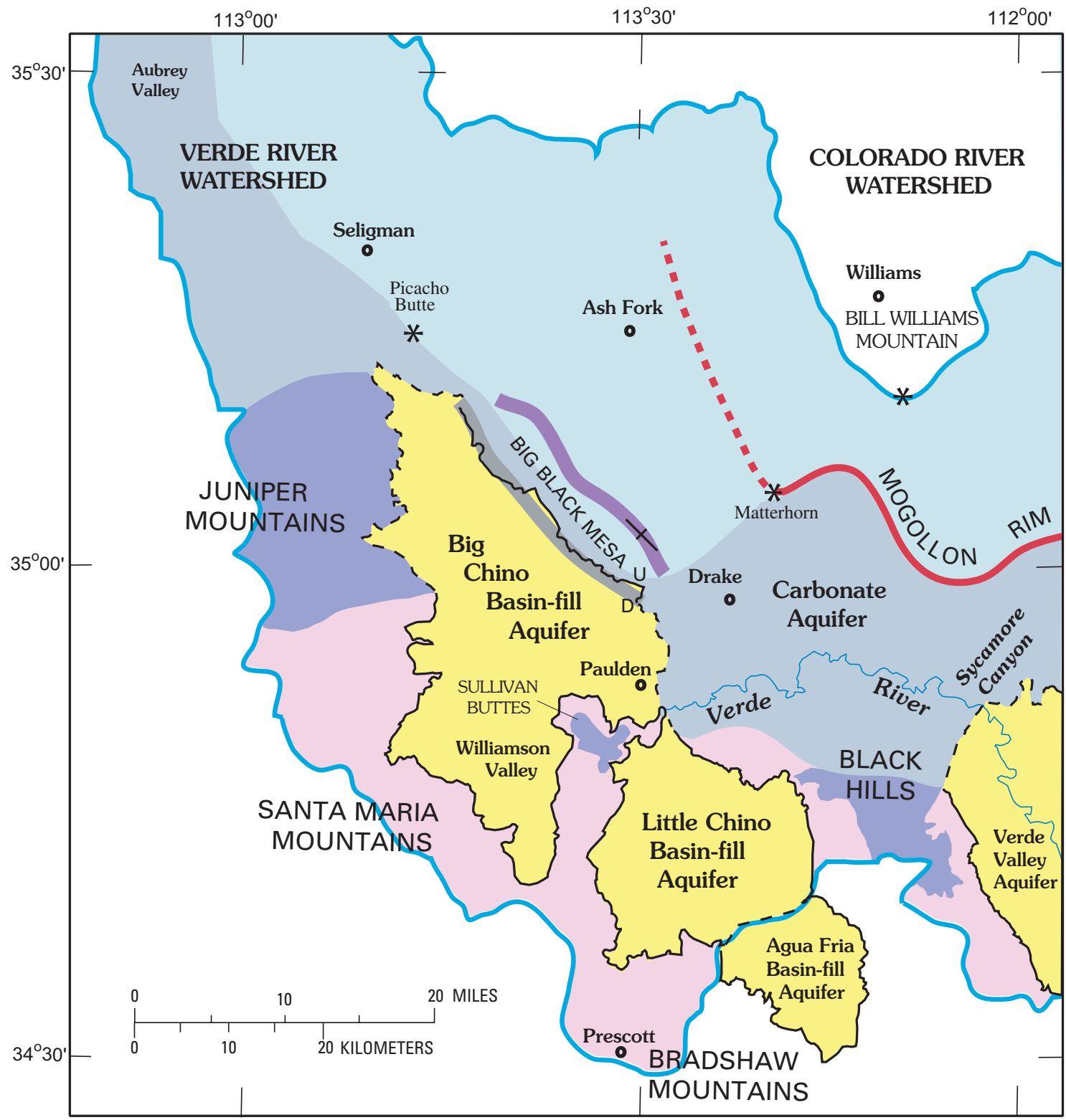

\section{EXPLANATION}

Carbonate aquifer; moderate to high permeability; beneath Colorado Plateau Carbonate aquifer; moderate to high permeability; Transition Zone; connected to Colorado Plateau

Carbonate remnant; moderate to high permeability; Transition Zone; disconnected from Colorado Plateau

Igneous and metamorphic rocks; low permeability

Basin-fill aquifer, moderate to high permeability; Transition Zone, boundary dashed where likely interconnected with adjacent aquifer

Verde River watershed boundary

Big Chino Fault; $U$, upthrown side; D, downthrown side

Limestone Canyon monocline, symbol indicates vertical dip of beds

Figure 5. Schematic diagram of basin-fill aquifer boundaries in relation to geologic provinces and different parts of the regional carbonate aquifer, upper Verde River watershed. Base is from U.S. Geological Survey digital data 1:100,000. 
Table 1. Relative porosity and permeability of stratigraphic units.

\begin{tabular}{|c|c|c|c|c|c|}
\hline Period & Map unit & Stratigraphic unit & Primary porosity & Secondary porosity & $\begin{array}{c}\text { Overall } \\
\text { permeability }\end{array}$ \\
\hline \multirow[t]{7}{*}{ Quaternary } & Qal & alluvium & high & & high \\
\hline & Qf & fanglomerate & high & & high \\
\hline & Qt & gravel & high & & moderate \\
\hline & Qg & gravel & high & & high \\
\hline & Qs & undivided sediment & moderate & & moderate \\
\hline & QTf & fanglomerate & moderate & & moderate \\
\hline & QTs & undivided sediment & moderate & & moderate \\
\hline \multirow[t]{16}{*}{ Tertiary } & Taby & alkali basalt & low & high & high \\
\hline & Tby & basalt & low & high & high \\
\hline & Tcy & cinders & high & & high \\
\hline & Tsy & conglomerate & high & & high \\
\hline & Tabo & alkali basalt & low & high & moderate \\
\hline & Tso & conglomerate & high & & high \\
\hline & Thb & basalt & low & high & moderate \\
\hline & Tha & trachyandesite & low & moderate & moderate \\
\hline & Ths & conglomerate & high & & high \\
\hline & Tlau & upper lati-andesite & low & moderate & moderate \\
\hline & Tlal & lower lati-andesite & low & moderate & moderate \\
\hline & Tla & $\begin{array}{l}\text { undivided lati- } \\
\text { andesite }\end{array}$ & low & moderate & moderate \\
\hline & Tla & $\begin{array}{l}\text { lati-andesite } \\
\text { intrusive centers }\end{array}$ & low & low & low \\
\hline & Tla & breccia & moderate & & moderate \\
\hline & Tla & cinders & moderate & & moderate \\
\hline & Tos & conglomerate & high & & high \\
\hline Permian & Ps & sandstone & moderate & & moderate \\
\hline Mississippian & $\mathrm{Mr}$ & limestone & moderate & high & high \\
\hline Devonian & $\mathrm{Dm}$ & dolomite & moderate & moderate & moderate \\
\hline Cambrian & $\mathrm{Ct}$ & sandstone & low & & low \\
\hline \multirow[t]{8}{*}{ Proterozoic } & $\mathrm{Xq}$ & quartzite & very low & & very low \\
\hline & $\mathrm{Xpr}$ & granodiorite & very low & & very low \\
\hline & Xap & aplite-pegmatite & very low & & very low \\
\hline & Xwv & granodiorite & very low & & very low \\
\hline & $\mathrm{Xp}$ & pelitic schist & very low & moderate & low \\
\hline & $\mathrm{Xgb}$ & gabbro & very low & & very low \\
\hline & $\mathrm{Xb}$ & metabasalt & low & moderate & low \\
\hline & $\mathrm{Xt}$ & metatuff & very low & moderate & moderate \\
\hline
\end{tabular}

Tapeats Sandstone and the Devonian Martin (Beus, 1989). Three facies are recognized in the Chino Valley Formation; a lithic sandstone, a pebble conglomerate, and a red shale-like dolomite.

The Martin Formation is comprised predominantly of dolomite, followed by minor limestone, interbedded argillaceous and arenaceous units, and minor amounts of limey siltsone and sandstone. It is easily distinguished by its gray color and evenly-bedded, step-like characteristics in outcrop (Krieger, 1965). Near Drake, the Martin ranges in thickness from 300 to $400 \mathrm{ft}$. The Martin crops out on Big Black Mesa, in the Juniper Mountains, and throughout much of the upper
Verde River canyon between Stillman Lake and the Paulden gauge. The Martin contains fractures and solution features, which are evident in Verde River canyon exposures near upper Verde River springs (fig. 2; Knauth and Greenbie, 1997).

The Martin is unconformably overlain by the Mississippian Redwall Limestone, except where eroded at the surface. The Redwall, which has a thickness of about $200 \mathrm{ft}$ near Drake, is a massive, cliff-forming unit (fig. 6). In the Grand Canyon region it is well known for its large caverns, collapse features, and extensive caves and springs (for example, Stanton's Cave, Redwall Cavern, and Vasey's Paradise). 


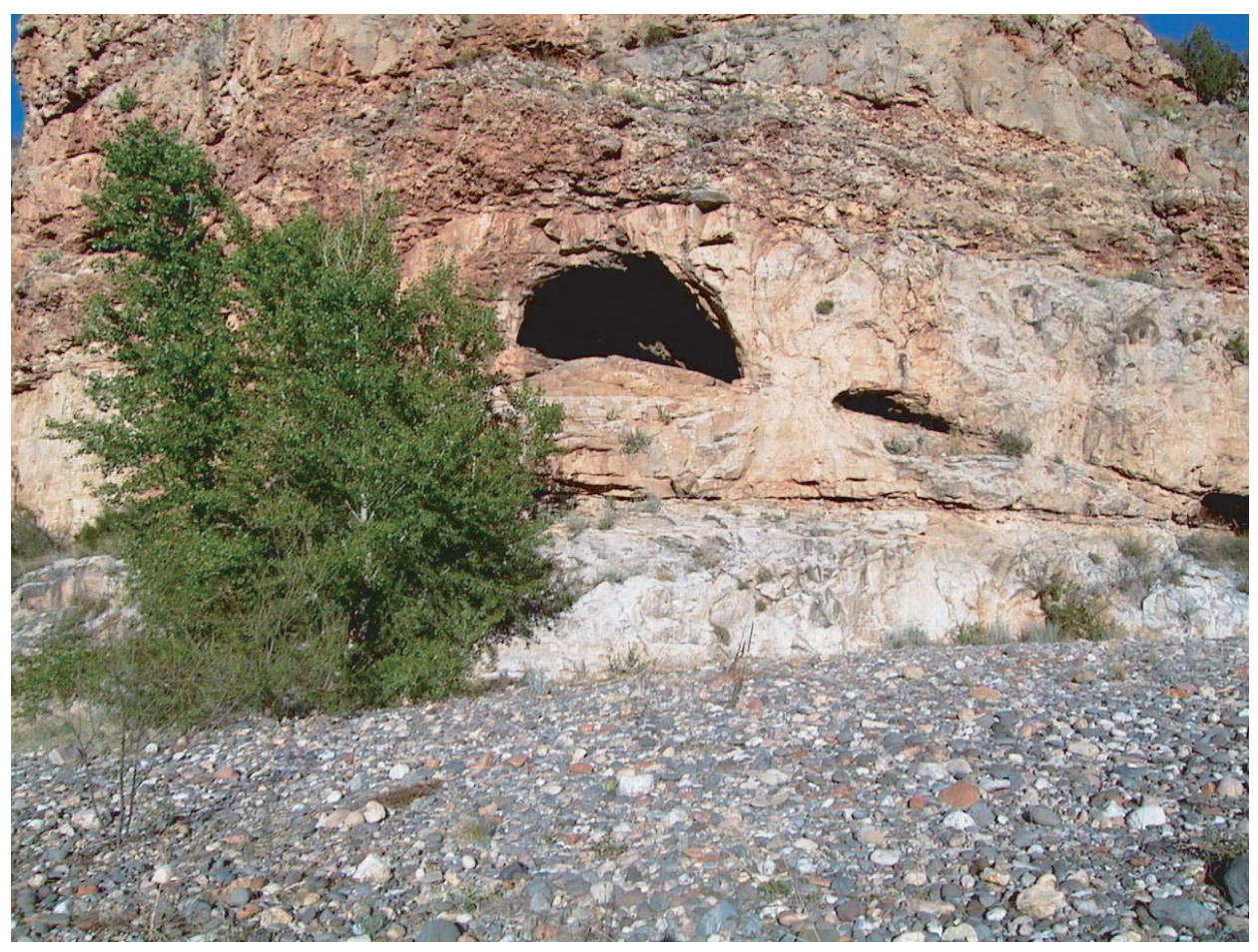

Figure 6. Photograph of large solution features in Redwall Limestone in upper Verde River canyon. (Photograph by L. Wirt, U.S. Geological Survey.)

Large springs at Mormon Pocket and Summers Spring in Sycamore Canyon emerge through the Redwall near its lower contact with underlying Martin. Dissolution openings, known as karst, offer the potential for water to travel rapidly through the subsurface (White, 1969, 1988, 1999; Ford, 1999; Ford and Williams, 1989). The solution channels and saturated caverns can store and transmit large amounts of water. Paleozoic rock units tend to be hydraulically connected both laterally and vertically by interconnected fractures and karst (Twenter and Metzger; 1963; Owen-Joyce and Bell, 1983).

The irregular distribution of fractures can result in confined aquifer conditions. Confined conditions occur at the 700ft Drake Cement well at Drake (SB-0001), which was drilled through unsaturated basalt, Redwall, and Martin; into what probably is the Chino Valley or upper Tapeats. Upon penetrating the lower Martin, the water level rose nearly $300 \mathrm{ft}$ within the borehole (Southwest Groundwater Consultants, 2002; William G. Wellendorf, written commun., 2002). Subsequent inspection with a down-hole camera showed a pronounced increase in the number of fractures and solution features near the base of the Martin relative to the overlying units. The static water level of the well (4,244 ft; table 2; Southwest Groundwater Consultants, written commun., 2004) is similar in elevation to the streambed in nearby Hell Canyon. Hell Canyon is probably a source of local recharge.

The lower Martin Formation is host to several prominent springs in the Verde River watershed, including upper Verde
River springs, spring-fed Stillman Lake near Paulden, the unnamed spring near the confluence of the Verde River and Muldoon Canyon (fig. 2; river mile 8), and Allen Springs on Mingus Mountain that are used as the sole water supply for the town of Jerome (Paul Lindberg, oral commun., 2002). The Martin is similar in composition and thickness to the Cambrian Muav Limestone that is host to many springs in the Grand Canyon.

In the Grand Canyon, most springs in the lower Paleozoic section generally discharge above the Bright Angel Shale, which is a relatively impermeable rock unit. A small quantity of water evidently penetrates the shale, as evidenced by smaller springs in the shale and underlying rock. The Bright Angel Shale has been recognized for its properties in retarding the downward percolation of ground water (Metzger, 1961; Twenter, 1962; Huntoon, 1977; Myers, 1987). The shale in the Bright Angel and the highly-cemented sandstone layers in the Tapeats impede downward movement and cause ground water to move laterally above the contact. This accounts for the accumulation of ground water in the overlying formation, the Muav Limestone.

In the Verde River watershed, the relation between the Martin and underlying Chino Valley Formation and the Tapeats Sandstone is analogous to the relation between the Muav Limestone and the underlying Bright Angel Shale. Many of the springs along the upper Verde River discharge just above the contact of these formations. 
Table 2. Water-level measurements for wells in the carbonate aquifer north of the upper Verde River.

[Well locations shown on fig. 9. ADWR = Arizona Department of Water Resources (2002); USGS = U.S. Geological Survey (Bills and Flynn, 2002);SGC = Southwest Groundwater Consultants (2002); WRA = Water Resources Associates (1990, 1991)]

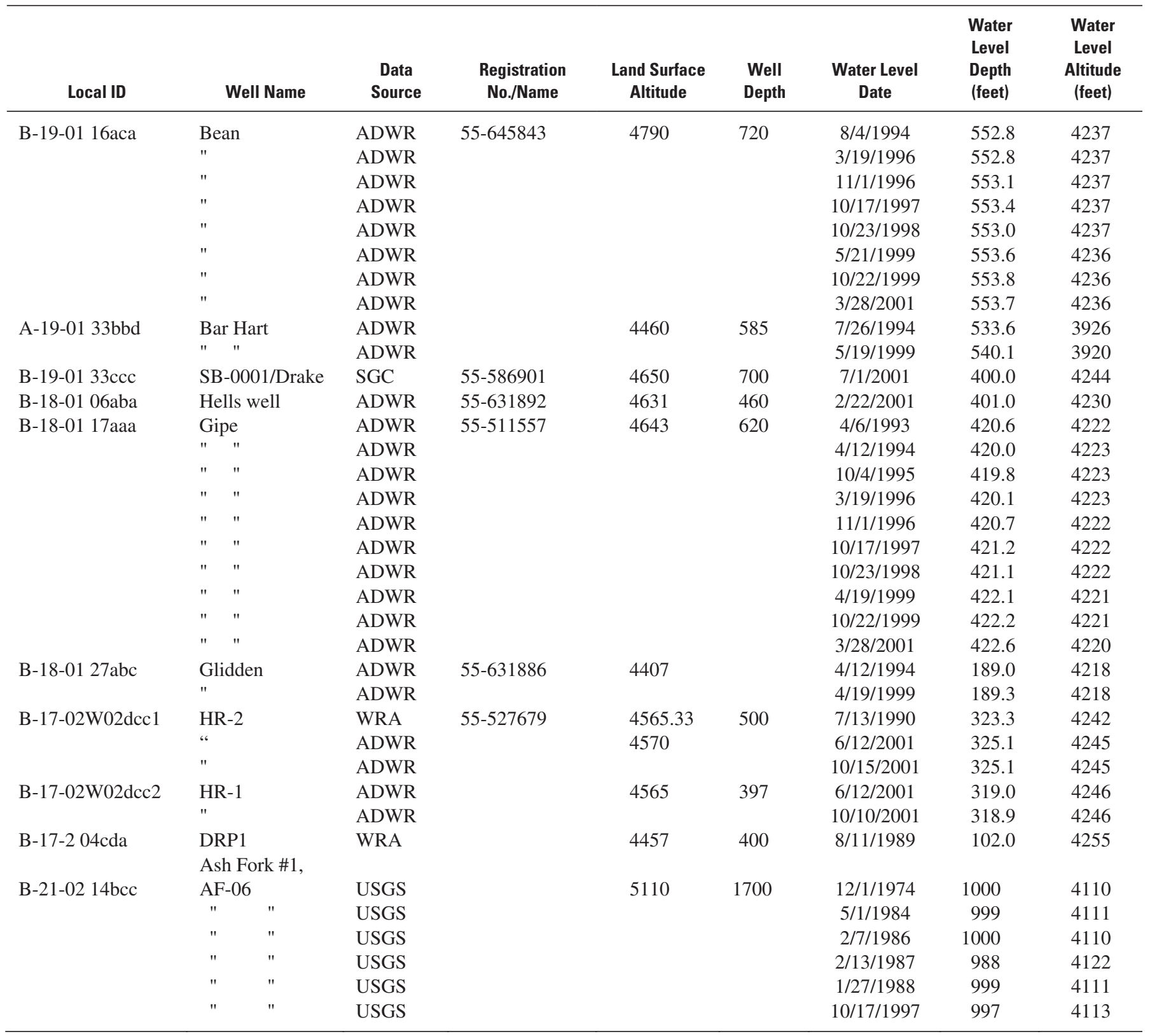

\section{Water-Bearing Characteristics of the Carbonate Aquifer North of the Verde River}

Wells in the carbonate aquifer north of the Verde River near Drake are from 480 to $720 \mathrm{ft}$ in depth (table 2). Based on the small number of wells, water yields are highly variable. Some of the wells are highly productive, and some are not. Dry holes north of the Bar Hart Ranch have been drilled as deep as $700 \mathrm{ft}$, and well drilling throughout this region is considered risky (Don Varner and David Gipe, local ranchers, oral commun., 2002).
As mentioned earlier, well SB-0001 is completed in what is interpreted from the driller's log as near the basal contact of the lower Martin with the Chino Valley or Tapeats (Southwest Groundwater Consultants, 2002). Based on a down-hole camera survey, this stratigraphic interval was observed to have a pronounced increase in the number of fractures and solution features relative to overlying units. This same interval is exposed in the upper Verde River canyon at several locations where there is spring discharge - e. g. at river mile 2.3 (upper Verde River springs), and at river mile 8.0 (unnamed spring near Muldoon Canyon). 
The Drake Cement well SB-0001 is presumed to be highly productive (Southwest Groundwater Consultants, 2002), although no aquifer tests of this well have been conducted. In fact, no aquifer tests are known to have been conducted for any wells in the carbonate aquifer near Drake. The well logs of two other wells near Drake are fairly similar to well SB-0001. A 620-ft stock well two miles south of Drake at B-18-01 17AA (known as the Gipe well) penetrated unsaturated basalt from 96 to $138 \mathrm{ft}$, which is underlain by conglomerate and limestone. A 720-ft stock well two miles northeast of Drake at B-19-01 16ACB (known as the Bean well) is almost entirely completed in basalt. Both stock wells are typically pumped at a rate of about $10 \mathrm{gpm}$ (Don Varner and David Gipe, local ranchers, oral commun., 2002).

A second highly-productive well (Rancho Cielo well HR-2) in the carbonate aquifer is located just east of the Big Chino basin-fill aquifer, and $1.5 \mathrm{mi}$ north of both the upper Verde River springs and the Verde River at (B-17-02)02 dac1. Aquifer tests for this well were used by Southwest Groundwater Consultants as a proxy for hydrologic conditions at well SB-0001. The validity of this assumption will be addressed in Part II of this report. Well HR-2 penetrates a basalt-filled paleochannel that is cut into Paleozoic rock (DeWitt and others, in press). The driller's log indicates that the borehole initially penetrated $200 \mathrm{ft}$ of basalt, lost circulation for 265 $\mathrm{ft}$, and bottomed in what was described as sand, sandstone, or limestone above $500 \mathrm{ft}$. Lost circulation may be an indication of openings, such as columnar fractures, rubbles zones, or karst. The lowermost part of the log could be interpreted as penetrating buried Tertiary alluvium, or Martin, Chino Valley, or Tapeats at the bottom of the paleochannel (DeWitt and others, in press). Any of these units typically would have hydraulic conductivities comparable to fractured basalt, ranging from $10^{2}$ to $10^{3}$ (table 3 ). An aquifer test was conducted for two days at approximately 600 gpm, with $3.04 \mathrm{ft}$ of drawdown (Water Resource Associates, 1990, 1991). Transmissivity was estimated to be $122,800 \mathrm{gpd} / \mathrm{ft}$ by the Theis type-curve method, which assumes that the aquifer is homogeneous and isotropic. Although this assumption is invalid in this type of geologic setting, the tests do indicate that the basalt and carbonate aquifer units are highly transmissive between Paulden and upper Verde River springs.

Hydrologists have long known that volcanic and carbonate rocks can have considerable secondary porosity (such as rubble zones, fractures, and solution features) that are heterogeneous with a distribution of permeability spanning many orders of magnitude (Davis and Deweist, 1966; p. 348-349). Conduit flow paths can have hydraulic characteristics more like surface streams than ground water. A distinguishing feature of karst aquifers is that most ground-water discharge typically is funneled through interconnected secondary openings. In some aquifers, the entire discharge is delivered through a single conduit system and discharges to a single spring or spring network. This appears to be the situation for many of the springs discharging to the upper Verde River.
Table 3. Range in hydraulic conductivity of sediment and rock types found in Big and Little Chino basins (from Ewing and others, 1993).

\begin{tabular}{lcc}
\hline \multirow{1}{*}{ Rock Type } & \multicolumn{2}{c}{$\begin{array}{c}\text { Hydraulic conductivity } \\
\text { (feet per day) }\end{array}$} \\
\cline { 2 - 3 } & minimum & maximum \\
\hline unfractured limestone & $5 * 10^{-4}$ & $5 * 10^{0}$ \\
fractured limestone & $5 * 10^{-3}$ & $5 * 10^{2}$ \\
unfractured basalt & $1 * 10^{-8}$ & $1 * 10^{-4}$ \\
fractured basalt & $1 * 10^{-2}$ & $1 * 10^{3}$ \\
unfractured sandstone & $1 * 10^{-3}$ & $1 * 10^{2}$ \\
coarse sand and gravel & $1 * 10^{3}$ & $1 * 10^{5}$ \\
medium sand & $1 * 10^{2}$ & $1 * 10^{4}$ \\
fine sand & $1 * 10^{-1}$ & $1 * 10^{2}$ \\
playa deposits & $1 * 10^{-6}$ & $1 * 10^{-2}$ \\
\hline
\end{tabular}

In summary, well yields in the carbonate aquifer tend to be improved where the well intercepts basalt-filled paleodrainages, or the base of the Martin, or both. The Martin-Chino Valley-Tapeats stratigraphic interval is host to many of the springs, as well as some of the most productive wells in this region. The Drake Cement well produces from this same stratigraphic interval.

\section{Regional Water-Level Gradients}

Water-level gradients provide an indication of the directions of ground-water flow in an aquifer. Water-level contour maps of the Big and Little Chino basin-fill aquifers that were constructed in the early 1990's are represented in fig. 7 (based on Schwab, 1995 and Corkhill and Mason, 1995). Water-level data are sparse for the carbonate aquifer north of the upper Verde River, in the area within the brown rectangular outline (Levings and Mann, 1980; Owen-Joyce and Bell, 1983).

In the Transition Zone north of the upper Verde River, the regional direction of ground-water movement in the carbonate aquifer is east or southeast, as inferred from water-level altitudes of gaining reaches of the upper Verde River, springs, and wells in the carbonate aquifer north of the river (figs. 7-9 and table 2). New water-level measurements collected since 1993 include twice as many wells and spring locations for this area than earlier studies (Owen-Joyce and Bell, 1983; Levings and Mann, 1980). Individual water-level data are presumed accurate to within $\pm 10 \mathrm{ft}$, except where surveyed. In most cases, the vertical accuracy of land-surface elevations was estimated from USGS 7.5-minute quadrangle maps having 20-ft topographic contours. Two of the new sites are index wells in the Arizona Department of Water Resources monitoring program, which are measured annually. The index measurements have changed little from year to year, varying within $2.0 \mathrm{ft}$ over an 8-year period.

Water-level elevations in the carbonate aquifer directly north of upper Verde River springs vary between 4,244 and 4,205 ft in elevation, a range of about $40 \pm 10 \mathrm{ft}$. This area, which lies between the 4,250 and 4,200 ft contours shown on 


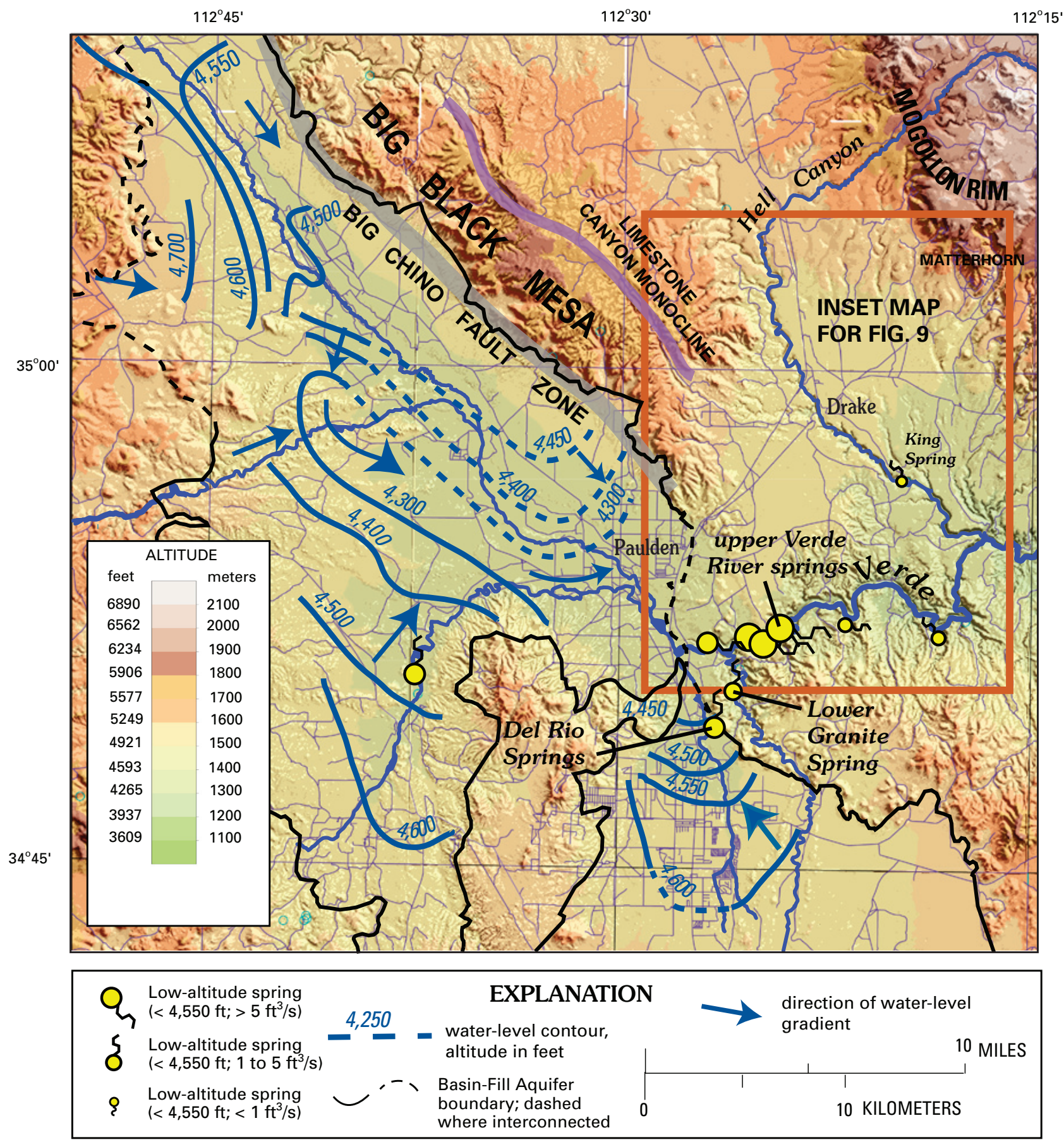

Figure 7. Compilation of water-level contour maps in the Verde River headwaters (after Schwab, 1995; Corkhill and Mason, 1995). Low-altitude springs shown as yellow circles, water-level contour elevations given in feet. Dashed contours and arrows are the author's interpretation. Base is from U.S. Geological Survey digital data 1:100,000.

figure 9, extends from Paulden on the west to Drake on the north, and from King Spring on the east to the upper Verde River to the south. The small range in water-level measurements for this area is notable despite the fact that different parties collected data in different years, using different methods and equipment, and in that topographic relief varies more than $400 \mathrm{ft}$ (fig. 9 and table 2). From west to east along the gaining reach of the Verde River, the water-level gradient slopes from about 4,255 ft near Paulden to 4,130 ft near Muldoon Canyon, about 25 feet per mile (ft/mi). From north to south, the gradient changes less than $5 \mathrm{ft} / \mathrm{mi}$ between Drake and upper Verde River springs. Owing to little well control, the $4,250 \mathrm{ft}$ contour could extend farther north of Drake along Hell Canyon, or 


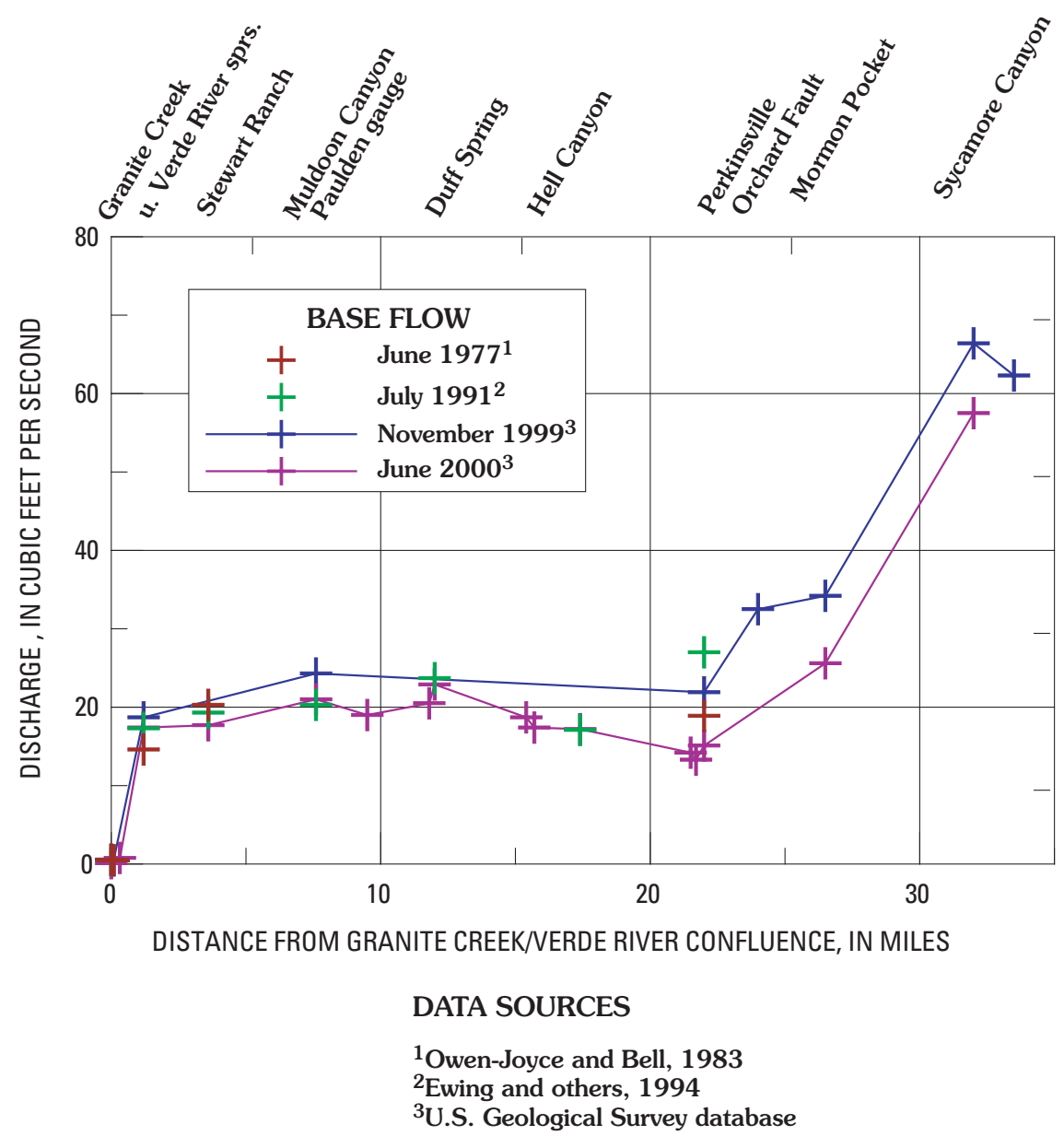

Figure 8. Graph showing changes in base-flow discharge with distance along the upper Verde River.

farther northwest beneath Big Black Mesa, but is well constrained to the east and south.

The water-level gradient near Drake slopes southeast toward King Spring, parallel to this reach of Hell Canyon. Hell Canyon probably is a linear source of recharge during large storm events that produce runoff or seasonal snowmelt. The part of Hell Canyon that is the source of ground water at Drake, however, is probably restricted to the reach within the Transition Zone. King Spring is a local point of discharge for this part of the carbonate aquifer, with evapotranspiration approximately equal to discharge (fig. 10). East of Hell Canyon, the water-level gradient declines abruptly by more than $300 \mathrm{ft}$ in less than a mile, which may indicate the presence of a structural barrier. From King Spring to Mormon Pocket and Sycamore Canyon (a distance of about $20 \mathrm{mi}$ ) water levels decline about $500 \mathrm{ft}$ or an average of $25 \mathrm{ft} / \mathrm{mi}$. The major ground-water flow direction between the town of Paulden and Hell Canyon is west to east; or northwest to southeast-parallel to the northwest-striking faults, monoclines, and fracture patterns. Underflow from Big and Little Chino Valleys past the mouth of Hell Canyon is presumed to be insignificant (Freethey and Anderson, 1986). Proterozoic rocks with low permeability crop out at river level between the Paulden gauge and Hell Canyon, which may contribute to the lack of measurable ground-water inflow to the upper Verde River between Hell Canyon and Perkinsville (fig. 8).

The water-level gradient between the Big Chino basinfill aquifer near Paulden (well DRP1) and upper Verde River springs is less than $10 \mathrm{ft} / \mathrm{mi}$. Ground water exits Big Chino basin-fill aquifer north and east of Paulden (figs. 7 and 9; Wallace and Laney, 1976; Owen-Joyce and Bell, 1983; Freethey and Anderson, 1986; Schwab, 1995) through Tertiary basalt and Paleozoic sedimentary rocks (fig. 3). The water-level gradient along the first $8 \mathrm{mi}$ of the upper Verde River $(25 \mathrm{ft} / \mathrm{mi})$ is about twice that of the gradient in Big Chino Valley (12 ft/mi). The lack of an abrupt change in the water-level gradient across the basin boundary between the Big Chino basin-fill aquifer and the carbonate aquifer is evidence that these two aquifers are hydraulically interconnected. The gradient and flow direction are consistent with the Big Chino aquifer providing the major source of discharge to upper Verde Springs, although it is possible that a fraction of inflow could be derived from the carbonate aquifer, which underlies all or most of Big Chino Valley and Big Black Mesa, as well as the confluence area 


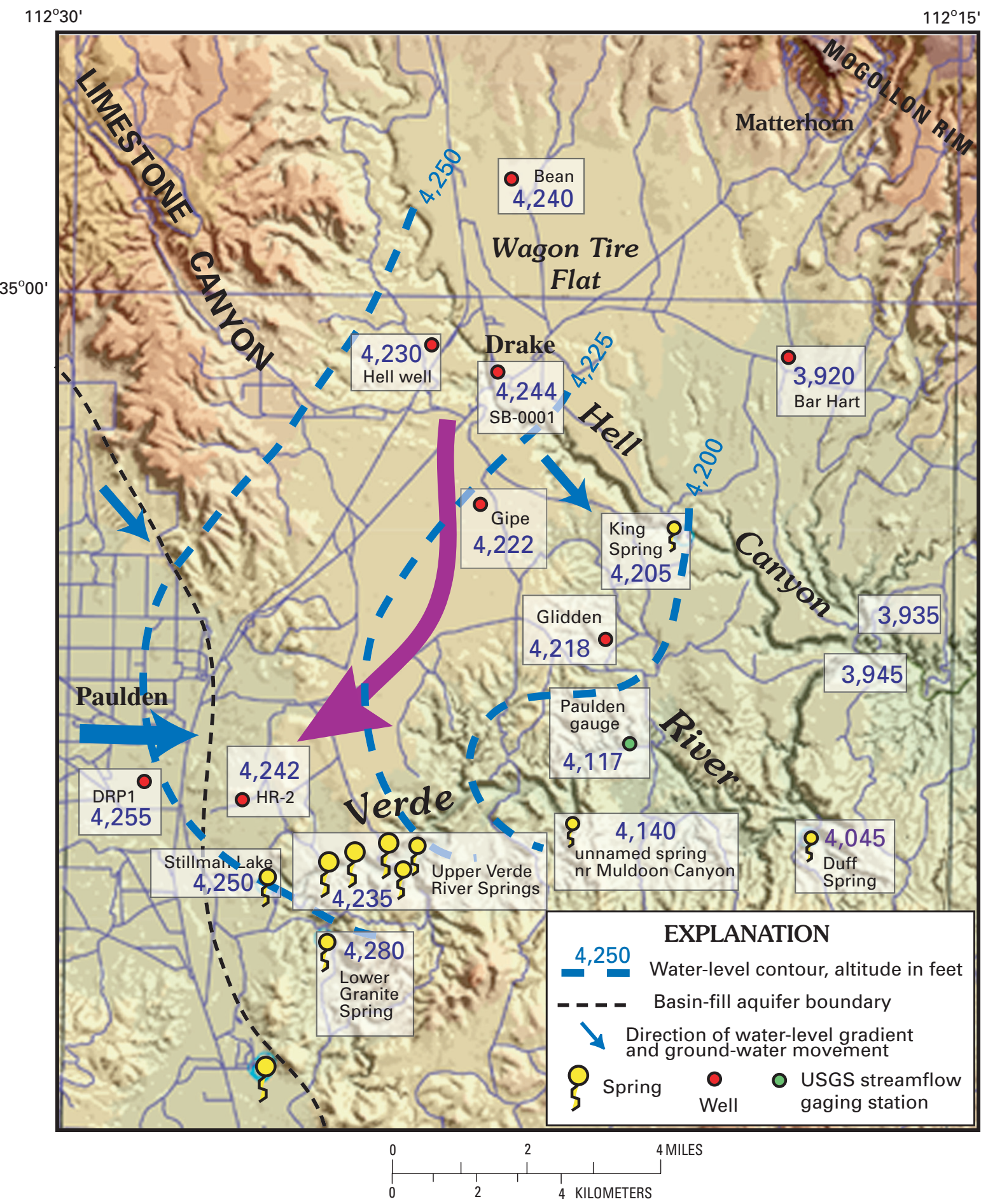

Figure 9. Water-level contour map of carbonate aquifer north of upper Verde River. Blue arrows indicate direction of ground-water movement. Two-sigma accuracy of water-level data within $20 \mathrm{ft}$ (data in table 2). Purple arrow is approximate location of buried basalt-filled paleochannel (DeWitt and others, in press). Base is from U.S. Geological Survey digital data 1:100,000.

with Granite Creek. Based on the water-level contours in figs. 7 and 9, all ground-water inflow to upper Verde River springs is derived from the west or northwest. Discharge from the carbonate aquifer could contribute to upper Verde River springs from Paleozoic rocks (a) beneath the Big Chino basin-fill aqui- fer, (b) along the base of Big Black Mesa, or (c) near the outlet of the basin-fill aquifer along a preferential flowpath that is parallel to the northwest-striking Big Chino Fault.

Ground water from the Big Chino aquifer travels through approximately two miles of carbonate aquifer before dis- 


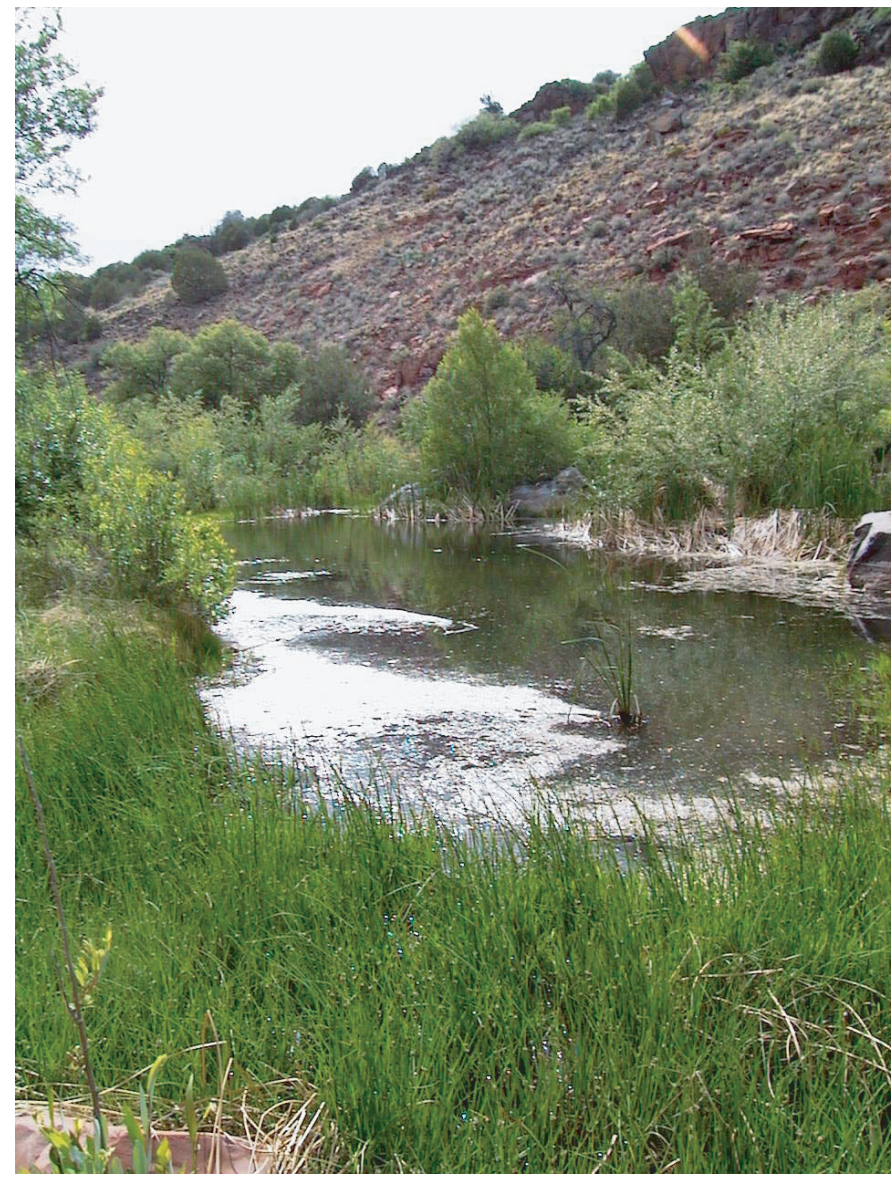

Figure 10. Photograph of King Spring in Hell Canyon. View is north. Rocks are Supai Formation capped with Tertiary basalt. The spring discharges from the carbonate aquifer where the land surface intersects the water table. (Photograph by L. Wirt, U.S. Geological Survey.)

charging to upper Verde River springs. Base flow measured downstream from the mouth of Granite Creek and upper Verde River Springs near Stewart Ranch (river mile 3.2; fig. 2) on June 17, 2000 was $19.5 \pm 1.0 \mathrm{ft}^{3} / \mathrm{s}$, compared with $21.2 \pm 1.0$ $\mathrm{ft}^{3} / \mathrm{s}$ at the Paulden gauge (river mile 10) during the same time interval (Wirt and others, in press). The difference in discharge is predominantly attributed to seepage near the confluence of Muldoon Canyon with the Verde River (fig. 9). On the basis of regional ground-water gradients, the source of the seepage may be from the west or northwest, which potentially could include a fraction of water from the carbonate aquifer in the Drake area, as well as any of the source areas for the upper Verde River. Some seepage could also be derived along Muldoon Canyon, from the south.

The reported water level of $4,244 \pm 1 \mathrm{ft}$ for well SB0001 is approximately $10 \mathrm{ft}$ higher than $4,235 \pm 1 \mathrm{ft}$ for upper Verde River springs. The elevation of first perennial flow in the Verde River used in this report is based on a high-vertical resolution, or "survey grade" global positioning survey (Maurice Tatlow, Arizona Department of Water Resources, written commun., 1999). This is similar to an independent measurement of $4,233 \pm 1$ for the water surface of the upper Verde River on April 29, 1991 with a level and rod survey, at location described as below the confluence of Granite Creek at river mile 2.5 (Water Resources Associates, 1991).

\section{Stable-Isotope Composition of Ground Water}

Ground-water samples from the carbonate aquifer north of Big Chino Valley and the upper Verde River have been analyzed for a variety of geochemical constituents, which help to verify hydrogeologic interpretations by providing multiple lines of independent evidence. The following discussion of the stable-isotope chemistry is abridged from a larger geochemical study of the Verde River headwaters region that includes Big and Little Chino Valleys (fig. 11) by Wirt and DeWitt (in press).

Water-chemistry samples for the Verde River headwaters region were grouped according to the three major aquifers and geographical location (fig. 11). Stable isotopes of hydrogen and oxygen in the ground and surface water of the study area were used to (1) indicate the degree of evaporation, (2) characterize and compare the isotope composition of major aquifers and springs, (3) trace water along flow paths, and (4) evaluate whether mixing may have occurred. One hundred-thirty seven well and spring samples collected from 1986 to 2003 were analyzed by three different stable-isotope laboratories (USGS in Reston, University of Arizona in Tucson, and Arizona State University in Tempe). Stable-isotope data are reported relative to Standard Mean Ocean Water (SMOW). Two standard deviation analytical precisions of 0.2 per mil $(\%)$ for $\delta^{18} \mathrm{O}$ and $2.0 \%$ for $\delta \mathrm{D}$ are assumed for all of data used in the study (Kendall and Caldell, 1998; p. 75; Christopher J. Eastoe, University of Arizona Laboratory of Isotope Geochemistry, oral commun., 2003). In graphs of $\delta^{18} \mathrm{O}$ and $\delta \mathrm{D}$, data typically are interpreted in relation to the World Meteoric Water Line (WMWL), or a local meteoric line (Craig, 1961). Most of the ground-water samples plot above both the Flagstaff Meteoric Water Line (FMWL; International Atomic Energy Agency, 2001) and the WMWL, indicating that the $\delta^{18} \mathrm{O}$ and $\delta \mathrm{D}$ of local precipitation recharged along the Mogollon Rim is more enriched than higher-altitude precipitation on the Colorado Plateau, as well as the global average.

The mean $\delta^{18} \mathrm{O}$ value for upper Verde River springs $(-10.3 \pm 0.1 \%$ o $)$ is most similar to the mean for samples from four wells penetrating the $\mathrm{D}-\mathrm{C}$ zone along the basin margin $(-10.4 \pm 0.3 \%)$, as indicated by a statistical summary of stableisotope data for the sample groups (fig. 12 and table 4). The mean $\delta^{18} \mathrm{O}$ value for the Big Chino sample group (-9.9 \pm 0.3$)$ and its range between the maximum of $-8.8 \%$ and minimum of $-10.5 \%$ is misleading in that it does not accurately represent a flow-weighted composite of ground water near the outlet of the basin-fill aquifer. The mean represents thirty-five well locations that were sampled on different dates from different screened intervals in the upper $700 \mathrm{ft}$ of the aquifer. In addition, the ${ }^{2} \mathrm{H}$ and ${ }^{18} \mathrm{O}$ content of ground water beneath Big 


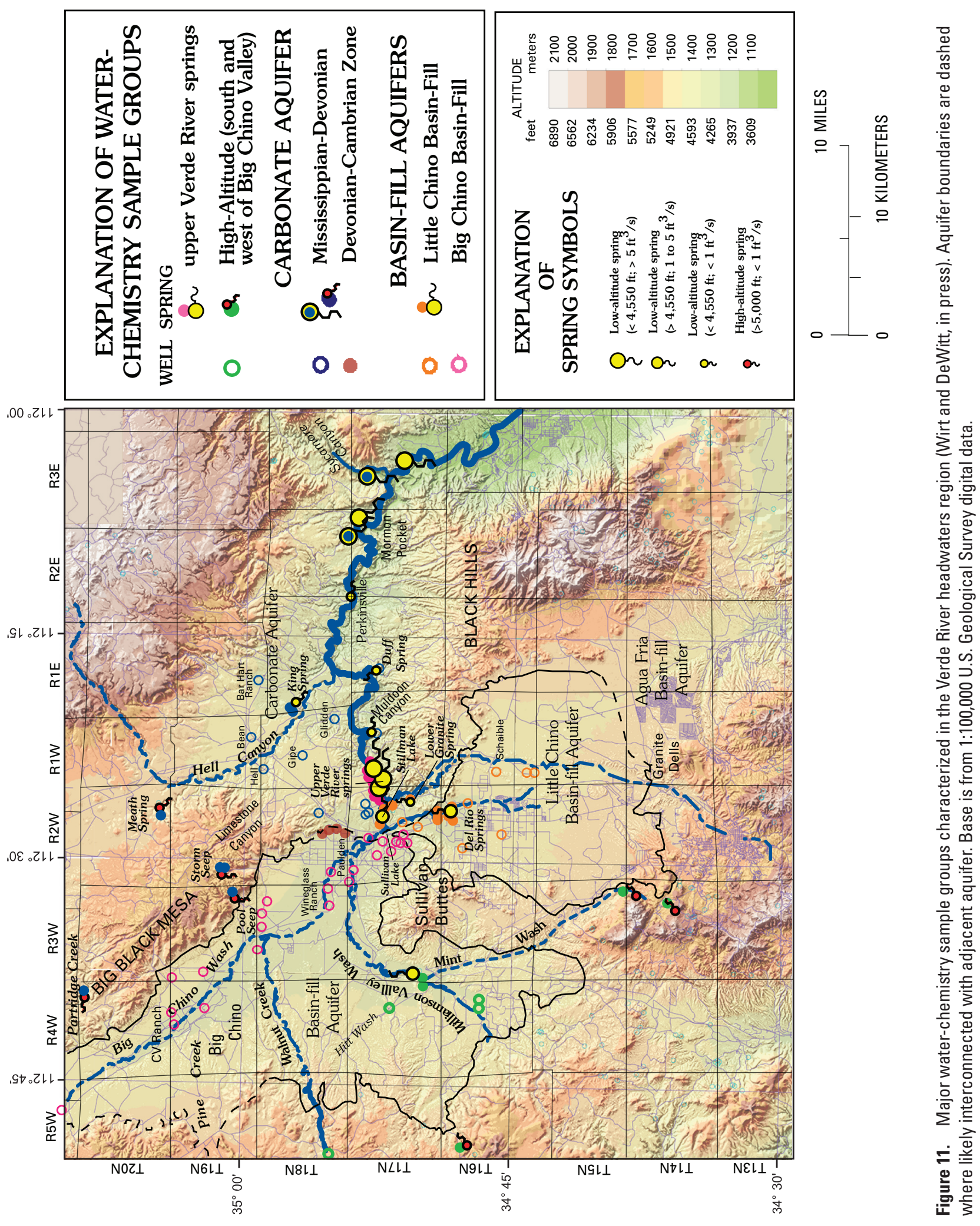


Chino Wash, Williamson Valley Wash, and near Sullivan Lake is potentially influenced by local recharge and likely enriched relative to the aquifer as a whole. Big Chino well samples near the outlet of the basin-fill aquifer are substantially more depleted in $\delta^{18} \mathrm{O}$ and $\delta^{2} \mathrm{H}$ than the group mean, and their isotope composition is indistinguishable from that of upper Verde River springs. For example, the $\delta^{18} \mathrm{O}$ of $-10.3 \%$ for ground water near Paulden (well (B-17-02)04ddc) is isotopically identical to the mean $\delta^{18} \mathrm{O}$ value for upper Verde River springs (table 4). A $\delta^{18} \mathrm{O}$ value of approximately $-10.3 \pm 0.2 \%$ o can be used to trace the main flowpath up-gradient from upper Verde River springs through the D-C zone to the outlet of the basin-fill aquifer near Paulden. Thus, no mixing of the Big Chino basin-fill aquifer with a second source is required to account for the stable-isotope composition at upper Verde River springs.

Figure $13 A$ compares variations in the ${ }^{2} \mathrm{H}$ and ${ }^{18} \mathrm{O}$ isotopic composition of upper Verde River springs with different geographical regions of the carbonate aquifer, including highaltitude springs on Big Black Mesa, deep wells north of the Verde River near Drake, large springs at Mormon Pocket and Sycamore Canyon, and the D-C zone beneath the margin of the Big Chino basin-fill aquifer. Figure $13 B$ compares samples from upper Verde River springs with those from the two basinfill aquifers and the high-altitude springs, tributaries, and wells west and south of Big Chino Valley.

Like the samples from springs at the ground-water outlet of the Little Chino basin-fill aquifer (Del Rio Spring,

\section{OXYGEN-18/OXYGEN-16 RATIO FOR MAJOR AQUIFERS AND SPRINGS, VERDE HEADWATERS, ARIZONA}

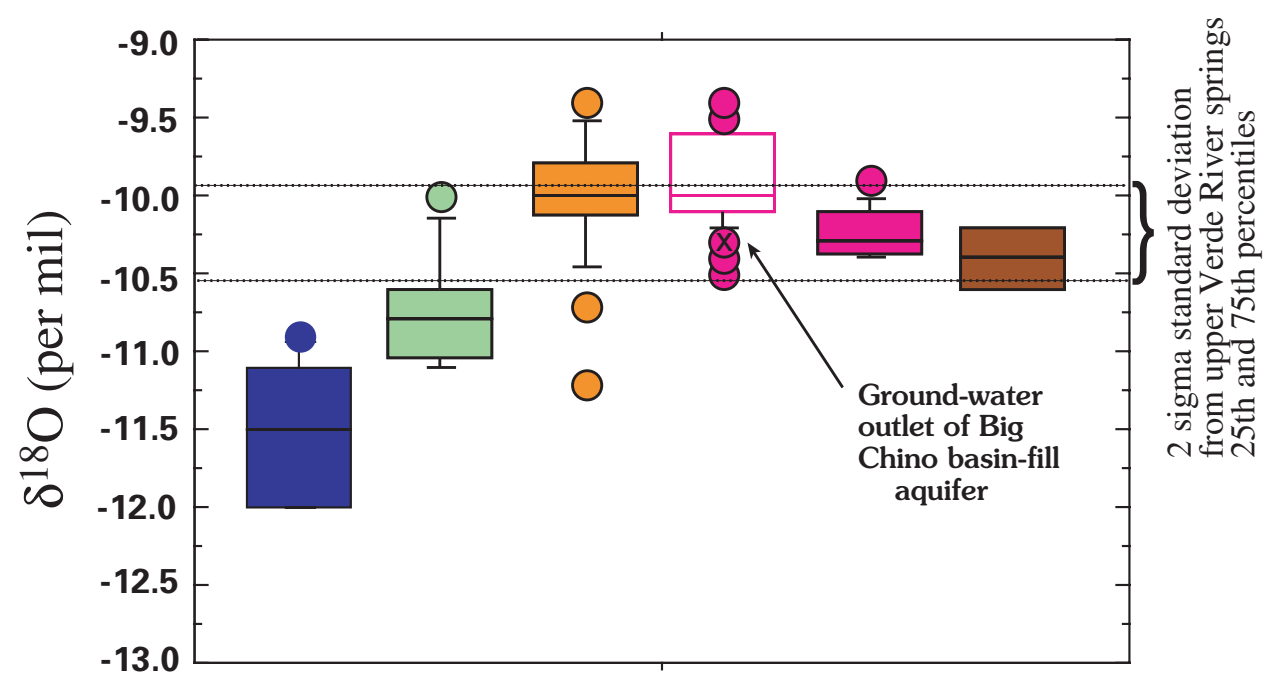

\section{EXPLANATION}

Carbonate aquifer north of the upper Verde River (Mississipian-Devonian sequence, $n=7$ ); King Spring samples interpreted as influenced by evaporation and therefore not included in statistical grouping

High-altitude springs and tributaries south and west of Big Chino Valley ( $\mathrm{n}=14$ sites)

Little Chino Basin-Fill Aquifer and Del Rio Springs ( $\mathrm{n}=22$ sites)

Big Chino Basin-Fill Aquifer ( $\mathrm{n}=35$ wells) The information displayed in box plots is summarized in the graphic below.

Paulden well B(17-02)04ddc at outlet of Big Chino basin-fill aquifer upper Verde River Springs ( $\mathrm{n}=11$ samples from 6 sites )

Devonian-Cambrian zone ( $\mathrm{n}=7$ samples from 4 wells)

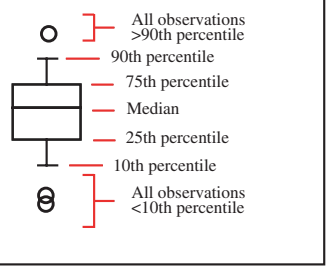

Figure 12. Box- and whisker plot (SAS Institiute, 1998) of $\delta^{18} 0$ for sample groups up-gradient of upper Verde River springs. Order of box- and whisker plots is the same as in explanation; outliers included; $n$, is number of samples. Data from Wirt and DeWitt (in press) are summarized in table 4. 

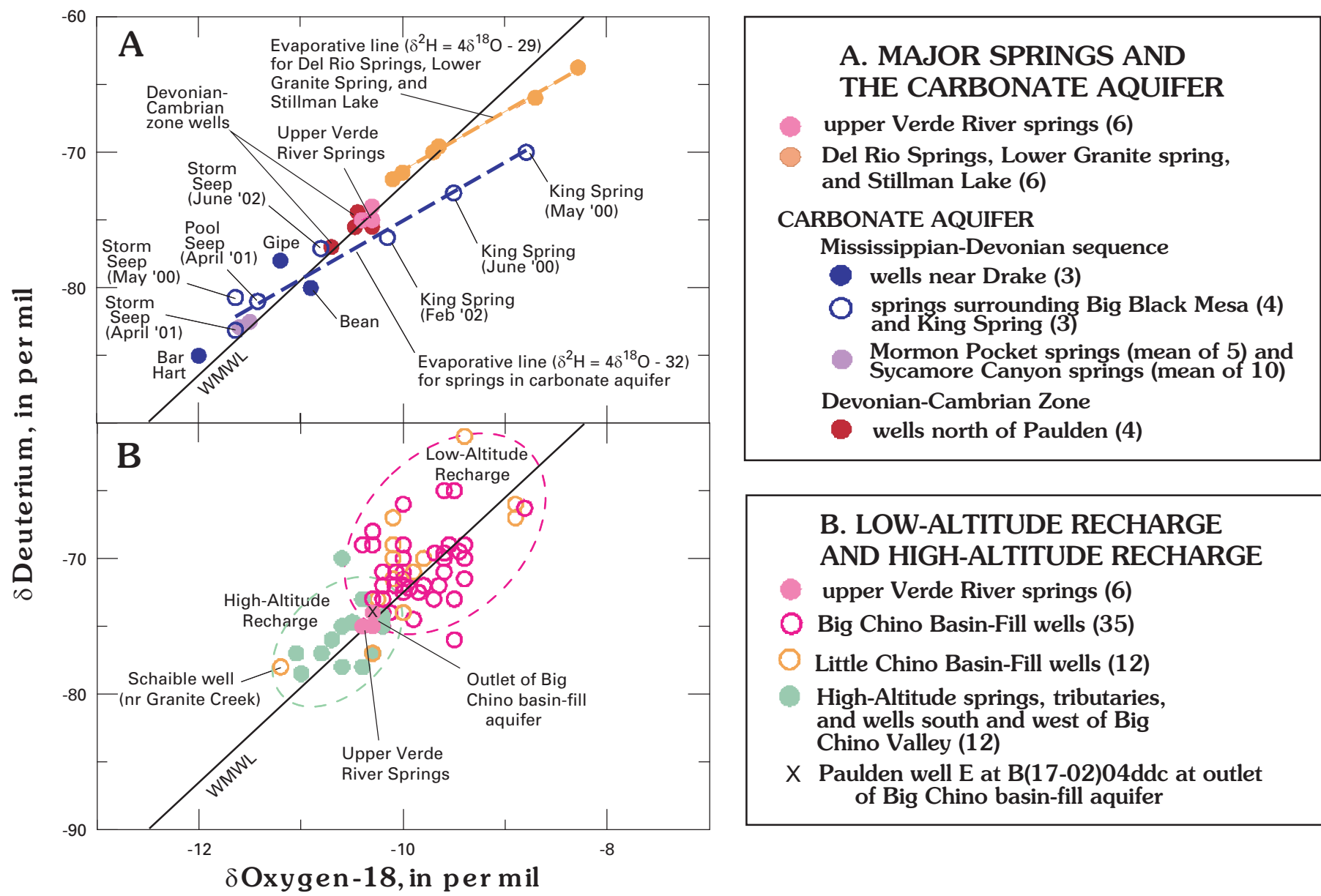

Figure 13. Graphs showing showing $\delta^{2} \mathrm{H}$ versus $\delta^{18} \mathrm{O}$ for sample groups in the Verde River headwaters, $A$ major springs discharging to the upper Verde River versus wells and springs in the carbonate aquifer, and $B$ upper Verde River springs versus low-altitude (basin-fill aquifers) samples and high-altitude springs, tributaries and wells. Number in parentheses in the explanation is number of sample locations. WMLW $=$ World Meteoric Water Line $\left(\delta^{2} \mathrm{H}=8 \delta^{18} \mathrm{O}+10\right), \mathrm{FMWL}=$ Flagstaff Meteoric Water Line $\left(\delta^{2} \mathrm{H}=6.5 \delta^{18} 0+9\right)$.

Stillman Lake, and Lower Granite Spring), the ${ }^{2} \mathrm{H}$ and ${ }^{18} \mathrm{O}$ isotopic composition of four samples collected from King Spring between May 2000 and June 2002 have undergone varying degrees of evaporation, as indicated by a slope of approximately 4 (fig. 13A). The dashed blue regression line for the King Spring samples is parallel to the regression line for Stillman Lake, Granite Creek and Del Rio Spring samples, also with a slope of 4. Left of the WMWL, the King Spring regression line intercepts several other spring samples from the carbonate aquifer near Big Black Mesa. Variation in ${ }^{2} \mathrm{H}$ and ${ }^{18} \mathrm{O}$ for three samples from Storm Seep, collected on different dates, are probably caused by seasonal variations in evaporation. A sample from Pool Seep plots within $-0.4 \%$ o $\delta^{18} \mathrm{O}$ of the Storm Seep sample, which were both collected on April 19, 2001. Isotopically lighter water from small springs such as Storm Seep and Pool Seep was collected near the point of ground-water discharge. These samples have undergone comparatively less evaporation than larger slow-moving water bodies such as King Spring or Stillman Lake, where the point of ground-water discharge is difficult to detect. The stable-isotope data independently corroborate the regional water-level gradient (Wirt, DeWitt, and Langenheim, in press), which indicates that the most likely sources of water to King Spring are depleted recharge from the Big Black Mesa area or local infiltration of runoff along Hell Canyon.

Not all samples in the regional carbonate aquifer have undergone substantial evaporation. Samples from three wells north of the upper Verde River (Bean, Gipe, and Bar Hart wells shown in figs. E1 and 13A) and large low-altitude springs at Sycamore Canyon and Mormon Pocket are an average of $1.3 \%$ more depleted than upper Verde River springs (table 4), plotting near or left of the WMWL. The wells range in depth from 585 to $720 \mathrm{ft}$, and all three wells were pumped extensively before sampling. The Sycamore Canyon and Mormon Pocket springs have been sampled repeatedly with little variation, which is attributed to steady discharge exceeding $5 \mathrm{ft}^{3} / \mathrm{s}$ for both of these large springs. In summary, the M-D sequence of the carbonate aquifer is substantially lighter in ${ }^{2} \mathrm{H}$ and ${ }^{18} \mathrm{O}$ than upper Verde River springs, and does not appear to contribute substantially to the upper Verde River upstream from Mormon Pocket (Wirt, 1993; Bryson and others, 2004). No mixing of the Big Chino basin-fill aquifer 
near Paulden (or D-C zone) with a second source is required to account for the stable-isotope composition at upper Verde River springs - although a standard analytical uncertainty of $0.2 \delta^{18} \mathrm{O} \%$ permits mixing with as much as 15 percent of the total discharge to upper Verde River springs to be derived from the M-D sequence of the carbonate aquifer without changing its isotopic composition. Ground water near Drake is interpreted as tributary to Hell Canyon and the upper Verde River, although the fraction of ground water that actually discharges as base flow is thought to be relatively small.

In summary, the carbonate aquifer north of the Verde River (M-D sequence) is on average 1.3\%o more depleted in $\delta^{18} \mathrm{O}$ than upper Verde River springs (table 4), or so enriched by evaporation that no conclusion can be made. Based on the regional water-level gradients, some discharge occurs at King Spring, and a small fraction of ground water from carbonate aquifer also may contribute to the upper Verde River (figs. 7 and 9). An estimate of 15 percent is considered possible although the contribution from the carbonate aquifer beneath Big Black Mesa (if any) could be smaller. Ford (2002) estimated recharge from the carbonate aquifer underlying Big Black Mesa at about five percent of the base flow to the upper Verde River. A five percent mix with the carbonate aquifer would be too small to produce a statistically significant shift in the $\delta^{2} \mathrm{H}$ and $\delta^{18} \mathrm{O}$ ratios. In addition, some local recharge probably occurs along Hell Canyon, which intersects the water table at King Spring. In conclusion, the carbonate aquifer near Drake is tributary to the upper Verde River, but does not appear to contribute substantially to the upper Verde River springs. Ground water near Drake most likely contributes to King Spring, in that it is similar in isotopic composition to discharge from King Spring that has corrected for evaporation. A small fraction of base flow in the upper Verde River, on the order of about 15 percent, could be derived from the carbonate aquifer.

\section{Part II. Adequacy of Data and Soundness of Conclusions}

The hydrology report by Southwest Groundwater Consultants (SWGC, 2002) relies on hydrologic information from aquifer tests of the Rancho Cielo HR-2 well for most of their assumptions about the Drake Cement well (SB-0001), as well as their 10-year impact analysis. SWGC assumes that the transmissivity, specific yield, and recharge characteristics of the Drake Cement site are similar to the Rancho Cielo site. The Rancho Cielo well is located about 5 miles south of the Drake Cement site, about 1.5 mi north of the Verde River, and 1.5 mi east of Paulden (figs. 7 and 9). 


\section{Hydrogeologic Framework}

Based on the information presented in Part I, it is evident that the hydrogeologic settings of wells SB-0001 and HR-2 have both similarities and differences. Both wells are located in the Transition Zone geologic province, and are completed in the regional carbonate aquifer north of the Verde River. Both boreholes penetrate thick basalt layers, and apparently produce from the water-bearing zone near the base of the Martin Formation. Both wells have similar water-level elevations (about 4,242 \pm 1 and 4,244 $\pm 1 \mathrm{ft}$ ), that are slightly higher than the beginning of the gaining reach for upper Verde River springs $(4,235 \pm 1 \mathrm{ft})$. Ground water at both sites is tributary to the upper Verde River.

At Drake, the top of the water table is about $400 \mathrm{ft}$ below ground surface (except in nearby Hell Canyon, where the water table is a short distance below the stream channel). During drilling, the Drake Cement well encountered the main water-bearing zone near the base of the Martin Formation (depth of $692 \mathrm{ft}$ ). The water level then rose approximately 300 $\mathrm{ft}$ in the borehole. This indicates the aquifer is under confined, or artesian conditions. Water-level gradients indicate that the most likely sources of ground-water recharge are Limestone Canyon (southeast flank of Big Black Mesa) and Hell Canyon (south of the ground-water divide).

At Rancho Cielo, the water level of the 500-ft well HR-2 is $325 \mathrm{ft}$ below the ground surface. The driller's notes do not indicate whether the initial water level during drilling was different than the reported static water level, probably owing to the loss of circulation. In the area near Paulden, however, ground water is usually unconfined or poorly confined (Wallace and Laney, 1976; Schwab, 1995). Hydraulic gradients and stable-isotope data indicate that the primary source of groundwater recharge is the Big Chino basin-fill aquifer.

The regional ground-water flow direction for both wells is similar, from northwest to southeast or west to east ${ }^{1}$ (fig. 9). The source of ground water to each well, however, is from different aquifers. Well SB-0001 probably receives high-altitude recharge exceeding 5,000 ft from the southeast flank of Big Black Mesa (Limestone Canyon) or along Hell Canyon. Ground water near Drake is at least 0.8 per mil more depleted in $\delta^{18} \mathrm{O}$ than upper Verde River springs. In contrast, the predominant source of ground water to well HR-2 is the Big Chino basin-fill aquifer.

No water chemistry samples are available for SB-0001 or HR-2; although chemical analyses are available from several nearby wells. Well HR-2 is about one mile east of Paulden well $\mathrm{B}(17-02) 04 d d c$ (fig. 13), and is presumed to have the

\footnotetext{
${ }^{1}$ Southwest Groundwater Consultants (SWGC, 2002) relies on a map of regional water levels in the Verde River watershed published by OwenJoyce and Bell (1983) that includes the region near Drake. The part of the 1983 map that is reproduced in SWGC Figure 1 of the application is now outdated because of new water-level data shown in fig. 9. SWGC shows the local ground-water flow direction near Drake as north of east, which is incorrect.
}

same or similar ground-water chemistry as other wells near Paulden (in both the basin-fill aquifer and the D-C zone of the carbonate aquifer) as well as upper Verde River springs (figs. 11 to13). Well SB-0001 is presumed to have stable-isotope chemistry similar to other wells in the carbonate aquifer near Drake, such as the Gipe or Bean wells (figs. 11 and 12, and shown as the M-D sequence whisker and box plot in fig. 13). Thus, the stable-isotope chemistry near the two wells is substantially different, which is consistent with two different ground-water recharge areas. Ground-water recharge is generally calculated as the sum of stream base flow, evapotranspiration, and ground-water underflow out of the basin of interest.

Ground-water recharge to Big Chino Valley is large, at about 21,500 acre-ft/yr (Freethey and Anderson, 1986; Ewing and others, 1994). In contrast, Ford (2002) estimated recharge surrounding Big Black Mesa at 1,250 acre-ft/yr based on its aerial extent exceeding 5,000 ft and a rate of precipitation between 16 and 18 inches. Thus, the two different source areas generate vastly different quantities of ground-water recharge.

The close proximity of Rancho Cielo well HR-2 to the Big Chino basin-fill aquifer and to the upper Verde River may account, in part, for the large reported transmissivity of 122,800 gpd/ft, discussed earlier in Part I. Because well HR-2 lies along the major flow path between the Big Chino basin-fill aquifer and upper Verde River springs, the aquifer test is indicative of non-homogeneous conditions along that flow path through karst, fractured basalt, and alluvial basin-fill deposits (fig. 3). The large transmissivity corresponds with other large transmissivities that have been reported for other nearby wells in the Big Chino basin-fill aquifer. For example, Water Resources Associates (1990) conducted an aquifer test of nearby well DRP1 (fig. 9) with a pumping rate of 5,000 gpm for 7 days that resulted in $3.31 \mathrm{ft}$ of total drawdown. The calculated rate of transmissivity and specific yield are 220,000 $\mathrm{gpd} / \mathrm{ft}$ and 0.29, respectively (Water Resource Associates, 1990; p. 14, phase IV, v. V), which makes well DRP1 one of the highest yielding water-supply wells in Big Chino Valley. Well DRP1 produces from fractured basalt flows similar to those penetrated by well HR-2.

The large transmissivity at well HR-2 could also be due to close proximity with the Verde River. According to the original consultant's report (Water Resource Associates, 1990; p. 13), "The flattening of the draw-down curve indicates that either steady-state conditions have been reached or leakage from the overlying volcanic units has stabilized the rate of draw down." As the overlying volcanic units are unsaturated, it is more likely such a situation indicates a line source or boundary condition at constant head, such as recharge from a perennial stream (Lohman, 1979; p. 58-61; Theis, 1941). Furthermore, although it appears that the Rancho Cielo well is highly productive, the aquifer tests did not adhere to Arizona Department of Water Resources recommendations such as the number of monitor wells, their location and type of construction, and no attempt was made to monitor discharge in the Verde River (Arizona Department of Water Resources, 1990a, 1990b, 1990c, 1991a, 1991b, 1991c). In short, the results of 
the Rancho Cielo aquifer tests are largely inconclusive. Based on differences in the degree of confinement, ground-water source area, and the amount of recharge available to each well, the Rancho Cielo aquifer tests may not accurately represent the hydrologic conditions at Drake. Consequently, the Rancho Cielo aquifer-test data used in the model simulation presented in the Stirling Bridge application (SWGC, 2002) should not be used as a proxy for SB-0001.

The recharge area west and north of Drake within the Transition Zone (the Big Black Mesa area) is small in aerial extent (figs. 5 and 9). The crest of Big Black Mesa is the approximate location of a ground-water divide for the carbonate aquifer between the Colorado Plateau and the Transition Zone (Wirt and DeWitt, in press). The location of the ground-water divide is inferred on the basis of the geologic framework and limited water-level data. Paleozoic units north of Big Black Mesa and the Mogollon Rim dip to the north or northeast. Relevant features important to the hydrogeologic framework include (a) northwest-striking faults, monclines, and fracture trends, (b) the stratigraphy and dip of the sedimentary rock units, and (c) karst. There are no wells on Big Black Mesa, but there are four high-altitude springs around the perimeter of Big Black Mesa that range in elevation from 5,000 to $5,700 \mathrm{ft}$ (fig. 11). High-altitude springs may or may not be directly connected to the underlying carbonate aquifer system, but their presence above the floor of Big Chino Valley suggests that the water table or the potentiometric surface is mounded beneath topographic highs.

The ground-water divide probably continues northeast of Big Black Mesa, toward the Matterhorn and Bill Williams Mountain, approximately following the northern boundary of the Transition Zone (figs. 4 and 5). The precise location of the ground-water divide between Drake and Ash Fork is uncertain, but it must exist for water-level gradients to slope towards the Verde River and Hell Canyon. Water-level measurements from deep municipal wells along I-40 near the towns of Ash Fork (4,095 to 4,114 ft) and Williams (between 3,900 and 4,100 ft) (Arizona Department of Water Resources, 2002; Bills and Flynn, 2002; Pierce, 2003) are substantially lower than water-level altitudes ranging between 4,205 ft at King Spring and 4,230 to 4,244 ft near Drake (table 2, fig. 9). In addition, measured water levels in Big and Little Chino Valleys and in the carbonate aquifer north of the upper Verde River all exceed $4,235 \pm 1 \mathrm{ft}$ in altitude - which is at least 100 feet greater than the elevation of measured water levels in the carbonate aquifer near Ash Fork and Williams. Owing to the ground-water divide and dip of the Paleozoic units to the north, the carbonate aquifer in the Drake area probably receives little if any ground-water contribution from the Paleozoic aquifer underlying the Colorado Plateau to the north.

As discussed earlier, Ford (2002) has estimated recharge beneath Big Black Mesa at 1,250 acre-ft/yr, based on the annual rate of precipitation. More than half of the recharge from Big Black Mesa area probably is inflow to Big Chino Valley, with the remainder to the carbonate aquifer east of Big Black Mesa, which is presumed tributary to the upper Verde
River. Because there is little, if any, ground water pumping on Big Black Mesa, ground-water recharge approximately equals discharge. Thus, the amount of recharge to the Drake area north of the Verde River is estimated at roughly half the recharge from Big Black Mesa, which is about 625 acre-ft/yr. Drake Cement is proposing to pump 70 acre-ft/yr, or about 11 percent of the ground-water recharge estimated to occur in this area.

\section{Potential Impacts to Water Resources of the Prescott National Forest and the Verde River}

The regional flow direction of the carbonate aquifer near Drake is southeast or east, along Hell Canyon toward King Spring, and ultimately toward the Verde River. This flow direction is parallel to major structural features such as the Big Chino Fault and Limestone Canyon monocline. Natural discharge predominantly occurs at King Spring and may possibly occur to small unnamed springs that provide inflow to the Verde River near Muldoon Canyon (figs. 2 and 8). Because of fractures and solution cavities in the limestone-and sparse well data-flow paths are difficult to determine precisely. Regional flow paths are all that are needed for this assessment, however, because it is certain that the water-level gradient near Drake is toward King Spring and the Verde River.

It is important to recognize interrelations between ground water and surface water, as well as between aquifers. Groundwater discharge sustains streams and is the source of springs and seeps along the upper Verde River canyon corridor and in Hell Canyon. The eventual consequence of any sustained ground-water withdrawal from the carbonate aquifer is a proportionate loss in discharge to other wells and springs discharging from the aquifer (Theis, 1940). The precise magnitude and timing of potential impacts, however, cannot be predicted from the available data.

Cones of depression (or dewatered cavities) often develop in response to long-term pumping, and their geometry in a karst aquifer is unpredictable. Because the water table varies by less than ten feet between the Drake area and the upper Verde River, continuous long-term pumping could eventually influence the present ground-water flow patterns, changing or even reversing flow directions. For example, sustained dewatering could divert ground water from other up-gradient areas, such as the Big Chino basin-fill aquifer near Paulden. On the other hand, future withdrawals from the Big Chino basin-fill aquifer could eventually lower the potentiometric surface of the carbonate aquifer near Drake.

The pumping currently proposed by the Drake Cement (on its private land associated with the cement plant) is approximately $70 \mathrm{ac}-\mathrm{ft} / \mathrm{yr}\left(0.25 \mathrm{ft}^{3} / \mathrm{s}\right)$ and is less than one percent of the 50th percentile daily mean flow duration of $25 \mathrm{ft}^{3} / \mathrm{s}$ at the USGS streamflow gaging station near Paulden (Fisk and others, 2004). Such an impact on the Verde River would be impossible to discern based on the accuracy of discharge measurements at the USGS streamflow gaug- 
ing station on the Verde River near Paulden (0939700). The time-weighted mean standard error of the daily low flow at the Paulden gauge has been calculated to be 4.6 percent by the USGS using the Moss and Gilroy method (Anning, 2004). In addition, it would it be difficult to differentiate the impact of the cement plant pumping on the Verde River from future impacts of larger ground-water withdrawals in Big and Little Chino Valleys (both ongoing and future). Of more practical concern then are local effects that the pumping could have on King Spring and nearby wells.

The primary water resources of the Prescott National Forest near Drake include the upper Verde River, King Spring, and several stock wells used by the grazing permit holder, which is the Alimeda Cattle Co. Stock wells near Drake in the regional carbonate aquifer include the Gipe, Bean, Hell, and Glidden wells (table 2). In addition, the privately-owned Bar Hart well is used for ranching and domestic water supply by the Alimeda Cattle Co. The Hell well lies closest to SB0001, but no well log is available for this or the Glidden well. The Gipe and Bean wells, and King Spring are interpreted as producing from the same water-bearing interval near the base of the Martin Formation as the Drake Cement well, and could be part of the same interconnected fracture system. The reported water levels for the Bean, Gipe, Hell, and Glidden wells are $7 \pm 10$ to $26 \pm 10 \mathrm{ft}$ lower than the water level reported for well SB-0001. On the basis of similar well depths and the small range in water levels, the Gipe, Bean, Hell, and Glidden wells and King Spring are the most likely areas to be affected by long-term pumping. The water level of the Bar Hart well is more than 300 feet lower than the Drake Cement well and, therefore, is unlikely to be influenced by pumping.

\section{Recommendations}

Any impact to base flow of the Verde River as a result of proposed pumping at this scale would be too small to measure. The proposed Drake Cement ground-water withdrawals would be impossible to differentiate from larger ground-water withdrawals (both current and proposed) that may reduce base-flow discharge of the upper Verde River in the future. The major concern, then, is to address possible local impacts to USFS permit-holder stock wells and to King Spring. The distribution and orientation of secondary openings in the carbonate aquifer cannot be mapped or predicted. As a result of this uncertainty, it is possible that the effects of pumping could be transmitted as much as several miles in any direction. Because some wells randomly intercept saturated pockets of ground water or the interconnected conduits between them, whereas other wells do not, storage coefficients in this type of aquifer can vary widely. A productive well penetrating a large saturated cavity might be pumped continuously for a long time at a high rate with no apparent effects, and then suddenly go dry when an overlying cavity is drained. Aquifer testing of well SB-0001 is unlikely to provide additional information that would be helpful in predicting this type of outcome. The best means to determine the long-term effects of pumping would be by establishing a monitoring program for existing wells and King Spring, and by conducting surveys of riparian habitat in Hell Canyon.

Therefore, a water-level monitoring program and riparian survey are advised. Ideally, a continuous water-level monitoring program would be established 6 months to a year before any pumping begins, in order to establish baseline conditions. Since 1994, water-level measurements of the Gipe and Bean wells have been conducted annually by the Arizona Department of Water Resources. Water levels in both wells have varied over a range of about $2 \mathrm{ft}$ over this timeframe (table 2). Annual monitoring, however, is insufficient to determine the nature of short- or long-term seasonal waterlevel variations caused by pumping as opposed to long-term climatic changes in evapotranspiration, runoff, and recharge. A greater frequency of measurements, interpreted in conjunction with climatic data, is needed to determine the expected normal range of water-level variations.

Owing to the small number of USFS wells in the vicinity of Drake, continuous water-level monitoring is recommended at all of them, specifically at SB-0001, Gipe, Hell, Bean, and Glidden wells and King Spring. However, there may be constraints to implementing such a plan because monitoring of wells on private lands would only be possible with the consent and cooperation of the private land owners. Assuming such cooperation could be obtained, continuous monitoring could be conducted using small submersible pressure transducers, which can be suspended on a wire cable in wells with active pumps. A simple staff gauge with a pressure transducer could also be installed at King Spring.

Pressure transducers are available that are automatically temperature-compensated and interface with battery-operated data logging devices. The devices can be downloaded without removing the monitoring installation from a well. Atmospheric barometric pressure has an effect on ground-water levels, and therefore should also be monitored at one central location. A suitable pressure transducer at the surface would suffice. Additional climatological data including temperature, precipitation, snowfall, and humidity are available from nearby weather stations at Ash Fork, Williams, and Chino Valley (Western Regional Climate Center, 2004).

The monitoring plan would need to be evaluated after the first year of monitoring to determine what frequency of future data measurements is needed, and to determine appropriate trigger points at which the data need to be reviewed or mitigation provided. An advantage of a long-term monitoring program for all parties is that if future demands for groundwater increase due to new or expanded federal land-use proposals there would be a history of information on which to base a management decision.

In order for water-level measurements to be more accurate, the elevations of well casings need to be surveyed to a precision of less than one foot. Given the relative lack of long-term variation in water-level measurements for the Gipe and Bean wells between 1994 and 2001 (Table 2), a water-level decline 
of greater than $2 \mathrm{ft} / \mathrm{yr}$, or more than $5 \mathrm{ft}$ in a 5 -yr timeframe at any of these wells would be considered an indication, or trigger point, that area water levels may be affected by ground-water withdrawals. In addition, a baseline survey of riparian habitat along Hell Canyon is recommended before mining commences. The survey should begin one mile upstream from the Drake quarry and extend one mile downstream from King Spring. In addition to vegetation and aquatic species, the occurrence of amphibian, reptile, and mammal species that depend on riparian habitat in Hell Canyon should be included in the survey. The survey should be updated in the event that a water-level decline at King Spring exceeds half its maximum depth, as pre-determined from the baseline water-level monitoring.

In addition, the Prescott National Forest could request a mitigation plan that would be implimented in the event that ground-water withdrawals were to adversely impact wells, springs, or riparian habitat. The mitigation plan, which would be negotiated and could be amended to the plan of operations, would include provisions for deepening wells or providing an alternate water supply for USFS stock wells that go dry as a consequence of dewatering. In the event of a reduction in discharge to King Spring, the proponent could agree to temporarily reduce or cease pumping of well SB-0001 until groundwater levels recover. For example, the proponent could haul water from an alternative water source until the water level of King Spring is restored to a pre-established baseline level.

King Spring at the base of Hell Canyon is the only natural water source within a three-mile radius. An inventory and assessment of wildlife species that depend on this water resource is recommended, regardless of the outcome of this mining application.

\section{References Cited}

Anning, D.W., 2004, Uncertainty in low-flow data from three streamflow-gaging stations on the upper Verde River, Arizona, in Sehlke, Gerald, Hayes, D.F., and Stevens, D.K., eds., Critical Transitions in Water and Environmental Resources Management, World Water and Environmental Resources Congress 2004, June 27-July 1, 2004, Salt Lake City, Utah, electronic book p. 1-8.

Arizona Department of Water Resources, 1990a, Internal memo from T. Perry to Steven Szyprowski, July 30, 1990.

Arizona Department of Water Resources, 1990b, Letter from Steven Szyprowski, Water Resources Section, to Richard T. Parker, Principal Planner, Yavapai County Planning and Building, August 8, 1990.

Arizona Department of Water Resources, 1990c, Letter from Steven Szyprowski, Water Resources Section, to Joseph Ayers, Headwaters Associates, Inc., August 27, 1990.
Arizona Department of Water Resources, 1991a, Letter from Steven Szyprowski, Water Resources Section, to Carlos D. Ronstadt, attorney, Snell and Wilmer Law Offices, February 25, 1991.

Arizona Department of Water Resources, 1991b, Letter from Greg Wallace, Chief Hydrologist, to Stephen Noel, Water Resources Associates, Inc., June 4, 1991.

Arizona Department of Water Resources, 1991c, Memo from Phil Foster, Director of the Prescott Active Management Area, to Steve Szyprowski, Water Resources Section, June 19, 1991.

Arizona Department of Water Resources, 2002, Arizona Registry of Wells 55 CD-ROM, updated March 2002.

Beus, Stanley S., 1989, Devonian and Mississippian Geology of Arizona: in Jenney, J.P., and Reynolds, S.J., Geologic evolution of Arizona: Tucson, Arizona Geological Society Digest 17, p. 287-311.

Bills, D.J., and Flynn, M.E., 2002, Hydrogeologic data for the Coconino Plateau and adjacent areas, Coconino and Yavapai Counties, Arizona: U. S. Geological Survey Open-File Report 02-265, 29 p. with CD-ROM.

Bryson, J.R., Ekwurzel, Brenda, and Hoffmann, J.P., 2004, Determination of ground-water flow paths using stable isotopes as geochemical tracers: Upper and Middle Verde River Watersheds, Arizona, USA: 2004 Annual Meeting, Geological Society of America Abstracts, v. 36, Paper No. 243-3.

Corkhill, E.F. and Mason, D.A., 1995, Hydrogeology and simulation of groundwater flow: Prescott Active Management Area, Yavapai County, Arizona: Arizona Department of Water Resources Modeling Report No. 9, 143 p.

Craig, H., 1961. Isotopic variations in meteoric waters: Science, v. 133, p. 1702-1703.

Davis, S.N., and DeWeist, R.J.M., 1966, Hydrogeology: John Wiley \& Sons, New York, p. 348-349.

DeWitt, Ed., Langenheim, V.E., and Wirt, L., (in press) Geological Framework: in Geologic framework of aquifer units and ground-water flow paths, Verde River Headwaters, North-Central Arizona: U.S. Geological Survey Open-File Report 2004-1411B.

DeWitt, Ed, Langenheim, V.D., Force, Eric, Vance, Kelly and Lindberg, P.A., with a digital database by Doug Hirschberg, Guy Pinhassi, and Nancy Shock, (in press) Geologic map of the Prescott National Forest and headwaters of the Verde River, Yavapai and Coconino Counties Arizona, U.S. Geological Survey Miscellaneous Investigations Map I-xxx, scale 1:100,000, two sheets. 
Ewing, D.B., Osterberg, J.C., Talbot, W.R., 1994. Big Chino Ground Water Study, Bureau of Reclamaation Technical Report, 3 sections.

Fisk, G.G., Duet, N.R., Evans, D.W., Angeroth, C.E., Castillo, N.K., and Longsworth, S.A., 2004, Arizona Water Resources Data-Water Year 2003: U.S. Geological Survey Water-Data Report AZ-03-1, 328 p.

Ford, D. C., 1999, Perspectives in karst hydrogeology and cavern genesis: in Karst Modeling, Karst Waters Institute Special Publication 5, p.17-29.

Ford, D.C., and P.W. Williams, 1989, Karst geomorphology and hydrogeology: London, Unwin and Hyman, 601 p.

Ford, J.R. 2002, Big Chino Valley ground water as the source of the Verde River: in Ground Water/Surface Water Interactions, July 1-3, 2002, American Water Resources Association summer specialty conference, $6 \mathrm{p}$.

Freethey, G.W., and T.W. Anderson, 1986, Predevelopment hydrologic conditions in the alluvial basins of Arizona and adjacent parts of California and New Mexico: U.S. Geological Survey Hydrologic Investigations Atlas HA-664.

Hereford, R. 1975, Chino Valley Formation (Cambrian?) in northwestern Arizona: Geological Society of America Bulletin, v. 86, p. 677-682.

Huntoon, P.W., 1977, Relationship of tectonic structure to aquifer mechanics in the western Grand Canyon District, Arizona: University of Wyoming, Water Resources Series No. 66, $51 \mathrm{p}$.

Hydrology Consultants, 1990, Headwaters Ranch Country Club Development Preliminary Groundwater Hydrology Report: Hydrology Consultants, certified by James Malone, July 22, 1990.

International Atomic Energy Agency, 2001. Isotope Hydrology Information System. The ISOHIS Database: Vienna, Austria, International Atomic Energy Agency: accessed May 21 at URL: http://ioshis.iaea.org.

Kendall, Carol, and Caldwell, E.A., 1998. Fundamentals of isotope geochemistry: in Kendall, Carol and McDonnell, J.J., ed., Isotope tracers in catchment hydrology: Elsevier, New York, Chapter 3, p. 51-86.

Knauth, L. P., and M. Greenbie. 1997. Stable isotope investigation of ground-water-surface-water interactions in the Verde River headwaters area: Arizona State University Department of Geology report in fulfillment of Arizona Water Protection Fund Grant \#95-001, administered by Arizona Department of Water Resources, 28 p.

Krieger, M.H., 1965, Geology of the Prescott and Paulden quadrangles, Arizona. U.S. Geological Survey Professional Paper 467, $127 \mathrm{p}$.
Langenheim, V.E., DeWitt, Ed, and Wirt, Laurie, (in press), Geophysical framework based on analysis of aeromagnetic and gravity data: in Geologic framework of aquifer units and ground-water flow paths, Verde River Headwaters, North-Central Arizona: U.S. Geological Survey Open-File Report 2004-1411C.

Levings, G.W., and Mann, L.J., 1980, Maps showing groundwater conditions in the upper Verde River area, Yavapai and Coconino Counties, Arizona-1978: U.S. Geological Survey Water-Resources Investigations, Open-File Report 80-726, maps.

Lohman, S. W., 1979, Ground-Water Hydraulics: U.S. Geological Survey Professional Paper 708, 70 p.

Metzger, D.G., 1961, Geology in relation to availability of water along the South Rim, Grand Canyon National Park, Arizona: in Hydrology of the Public Domain, U.S. Geological Survey Water-Supply Paper 1475-C, p. 105-135, with plates.

Myers, S.M., 1987, Map showing ground-water conditions in the Peach Springs basin, Arizona: Arizona Department of Water Resources, Hydrologic Map Series Report no.15.

Owen-Joyce, S.J., and C.K. Bell. 1983. Appraisal of water resources in the Upper Verde River area, Yavapai and Coconino Counties, Arizona: Arizona Department of Water Resources Bulletin 2, 219 p.

Pierce, H.A., 2003, Structural controls on ground-water conditions and estimated aquifer properties near Bill Williams Mountain, Williams, Arizona: U.S. Geological Survey, Water-Resources Investigations Report 01-4058, 41 p.

Reynolds, S.J., 1988, Geologic map of Arizona: Arizona Geological Survey Map 26, scale 1:1,000,000.

Richard, S.M., and Kneale, S.M. (eds.), 1998, Geologic map of Arizona, GIS database: Arc/INFO export file (.e00) format, 2 disks, $10 \mathrm{p}$.

SAS Institute, 1998. StatView: Version 5.0.1, Cary, North Carolina.

Schwab, K.J. 1995. Maps showing groundwater conditions in the Big Chino Sub-Valley of the Verde River Valley, Coconino and Yavapai Counties, Arizona-1992: Department of Water Resources, Hydrologic Map Series Report Number 28, Phoenix, Arizona, 1 sheet.

Southwest Groundwater Consultants, 2004, C.V./C.F. Ranch Acquisition Hydrology Report: prepared for City of Prescott Public Works Department, June, 2004, 6 chapters plus oversized figures and appendix. 
Southwest Groundwater Consultants, 2002, Letter dated April 22, 2002 from William G. Wellendorf, to Mr. Cliff Ayers, Stirling Bridge Cement: Southwest Groundwater Consultants $6 \mathrm{p}$.

Southwest Groundwater Consultants, 2002, Hydrogeology Proposed Stirling Bridge Project, Drake, Arizona: Southwest Groundwater Consultants, August 8, 2002, 11 p.

Theis, C.V., 1940, The source of water derived from wells: Civil Eng., v. 10, no. 5, p. 277-280.

Theis, C.V., 1941, The effect of a well on the flow of a nearby stream: Am. Geophys. Union Trans., v. 22, p. 734-738.

Thorstenson, D.J., and Beard, L.S. 1998, Geology and fracture analysis of Camp Navajo, Arizona Army National Guard, Arizona: U.S. Geological Survey Open-File Report 98-242, $42 \mathrm{p}$.

Twenter, F.R., 1962, Geology and promising areas for groundwater development in the Hualapai basin area, Arizona: U.S. Geological Survey Water Supply Paper 1576-A, 38 p.

Twenter, F. R. and Metzger, D.G., 1963, Geology and ground water in Verde Valley - the Mogollon Rim region Arizona: U.S. Geological Survey Bulletin 1177, 132 p.

U.S. Forest Service, 2001, Water Uses and Development: Chapter 2540 in Watershed Forest Service Manual (FSM 2500) on Water and Air Management, Southwestern Region (Region 3), Supplement No. 2500-2001-1, Effective September 5, 2001, $11 \mathrm{p}$.

Wallace, B. L. and R. L. Laney. 1976. Maps showing groundwater conditions in the lower Big Chino Valley and Williamson Valley areas, Yavapai and Coconino Counties, Arizona - 1975-76: U.S. Geological Survey Water Resources Investigations 76-78 Open File Report, 2 maps.

White, W.B., 1999, Conceptual models for Karstic Aquifers: in Karst Modeling, Karst Waters Institute Special Publication 5, p. 11-16.

White, W.B., 1988, Geomorphology and hydrology of karst terrains: NewYork, Oxford University Press, 464 p.
White, W.B., 1969, Conceptual models for carbonate aquifers: Ground Water, v. 7, p. 15-21.

Wirt, Laurie (in press), The Verde River Headwaters, Yavapai County, Arizona: in Geologic framework of aquifer units and ground-water flow paths, Verde River Headwaters, North-Central Arizona: U.S. Geological Survey Open-File Report 2004-1411A.

Wirt, Laurie, 1993, Isotopic content and water chemistry of ground water that supplies springs in the Verde headwaters, Yavapai, County, Arizona. Paper submitted at the Fifth Annual Symposium of the Arizona Hydrological Society, Sedona, Arizona, September 10-12, 1992

Wirt, Laurie, and DeWitt, Ed, (in press), Geochemistry of major aquifers and discharge springs: Geologic framework of aquifer units and ground-water flow paths, Verde River Headwaters, North-Central Arizona: U.S. Geological Survey Open-File Report 2004-1411E.

Wirt, Laurie, DeWitt, Ed, and Langenheim, V.E., (in press), Hydrogeologic framework: in Geologic framework of aquifer units and ground-water flow paths, Verde River Headwaters, North-Central Arizona: U.S. Geological Survey Open-File Report 2004-1411D.

Wirt, Laurie, and Hjalmarson, H. W., 2000, Sources of springs supplying base flow to the Verde River headwaters, Yavapai County, Arizona: U.S. Geological Survey Open-File Report 99-0378, p. 50, illus. incl. 5 tables, geol. sketch maps.

Water Resource Associates, 1990, Hydrogeology investigation of Big Chino Valley, Yavapai County, Arizona: Phase II, Water Resources Associates, Inc. v. 3, 42 p. plus well logs.

Water Resource Associates, 1991. Application for a Subdivision Water Adequacy Statement Headwaters Ranch Project, Paulden, Arizona: Water Resources Associates, Inc., certified by Stephen Noel, May 10, 1991.

Western Regional Climate Center, 2004, Arizona Climate Summaries, accessed on December 1, 2004, http: //www.wrcc.dri.edu/summary/climsmaz.html. 